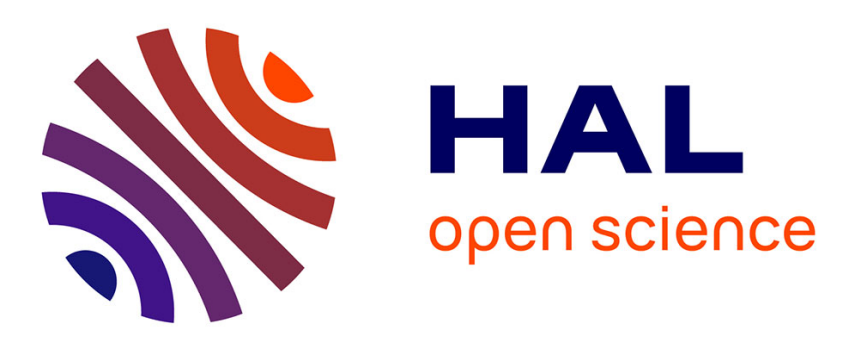

\title{
Integration of snow management processes into a detailed snowpack model
}

P. Spandre, S. Morin, M. Lafaysse, Y. Lejeune, H. François, E. Marcelpoil

\section{To cite this version:}

P. Spandre, S. Morin, M. Lafaysse, Y. Lejeune, H. François, et al.. Integration of snow management processes into a detailed snowpack model. Cold Regions Science and Technology, 2016, 125, pp.48-64. 10.1016/j.coldregions.2016.01.002 . hal-01360591

\section{HAL Id: hal-01360591 \\ https://hal.science/hal-01360591}

Submitted on 6 Sep 2016

HAL is a multi-disciplinary open access archive for the deposit and dissemination of scientific research documents, whether they are published or not. The documents may come from teaching and research institutions in France or abroad, or from public or private research centers.
L'archive ouverte pluridisciplinaire HAL, est destinée au dépôt et à la diffusion de documents scientifiques de niveau recherche, publiés ou non, émanant des établissements d'enseignement et de recherche français ou étrangers, des laboratoires publics ou privés. 


\title{
Integration of snow management processes into a detailed snowpack model

\author{
P. Spandrea,b, S. Morin ${ }^{b, *}$, M. Lafaysse ${ }^{b}$, Y. Lejeune ${ }^{b}$, H. François ${ }^{a}, E$. \\ George-Marcelpoil \\ arstea, UR DTM, Grenoble
} \\ bMétéo-France CNRS, CNRM-GAME UMR 3589, Centre d'Etudes de la Neige, Grenoble
}

\begin{abstract}
The understanding and implementation of snow management in detailed snowpack models is a major step towards a more realistic assessment of the evolution of snow conditions in ski resorts concerning past, present and future climate conditions. Here we describe in a detailed manner the integration of snow management processes (grooming, snowmaking) into the snowpack model Crocus. The effect of the tiller is explicitly taken into account and its effects on snow properties (density, snow microstructure) are simulated in addition to the compaction induced by the weight of the grooming machine. The production of snow in Crocus is carried out with respect to specific rules and current meteorological conditions. Model configurations and results are described in detail through sensitivity tests of the model of all parameters related to snow management processes. In-situ observations were carried out in four resorts in the French Alps during the 2014-2015 winter season considering for each resort natural, groomed only and groomed plus snowmaking conditions. The model provides realistic simulations of the snowpack properties with respect to these observations. The main uncertainty pertains to the efficiency of the snowmaking process. The observed ratio between the mass of machine-made snow on ski slopes and the water mass used for production was found to be lower than was expected from the literature, in every resort.

Nevertheless, the model now referred to as "Crocus-Resort" has been proven to provide realistic simulations of snow conditions on ski slopes and may be used for further investigations.
\end{abstract}

\footnotetext{
*. Corresponding author

Email address: samuel.morin@meteo.fr (S. Morin )
} 
Keywords: Snow management, grooming, snowmaking, snowpack modelling, French Alps, Ski resorts

\section{INTRODUCTION}

The management of snow on ski slopes is a key socio-economic and environmental issue in mountain regions. Indeed, the winter sports industry has become a very competitive global market (Agrawala et al., 2007). Ski lift operators face multiple expectations from both consumers and investors (Fauve et al., 2002; DSF, 2014) such as ensuring opening/closing dates and maintaining safe and homogeneous conditions, etc. Further to operating costs (Damm et al., 2014), the increasing attention paid to environmental issues (Steiger, 2010; Magnier, 2013) arouses the interest of both policy makers and ski lift operators concerning optimization levers of energy and water consumption and for reliable data concerning the ability of the snow industry to face climate challenges (Scott and McBoyle, 2007).

Several methods such as snow grooming are employed by ski resort operators to provide comfortable skiing conditions, to protect snow from natural and humaninduced ablation processes, or to compensate for snow deficits by means of snowmaking (Guily, 1991; Fauve et al., 2002). Snow management processes (grooming and snowmaking in particular) induce significant changes in the physical state and behaviour of the snowpack so that snow on ski slopes is markedly different from natural snow conditions in their surroundings (Fahey et al., 1999; Rixen et al., 2001). Indeed, be it fully natural or under the influence of human interference, snow cover constantly undergoes physical transformations which occur under the influence of atmospheric conditions (Armstrong and Brun, 2008) and due to the intrinsic physical properties of snow layers. These in turn influence the surface energy budget and the evolution of internal properties (Brun et al., 1992; Vionnet et al., 2012). An assessment of the snow conditions in ski resorts therefore requires a method which handles simultaneously physical processes occurring in snow and the impact of snow management practices. This is because the reaction of the snowpack to all of its drivers is strongly non-linear and is affected by several thresholds. 
However, investigations of the vulnerability of the ski industry have often been based on natural snow conditions and employed empirical rules (Crowe et al., 1973; Durand et al., 2009). Since the early 2000s, several studies have initiated accounting for snow management practices in assessments of snow conditions in ski resorts. Rixen et al. (2011) for example, computed potential snowmaking days based on climate projections of air temperature and humidity. These computations took place on several study sites in Switzerland without further analysis of snow conditions. This was due to the lack of a snowpack model able to process the information in question. Scott et al. (2003) implemented snowmaking operational rules in a simple snowpack model (degree-day approach). This was in order to assess the impact of climate change on ski season duration using various snowmaking technologies represented by different model configurations. However, this study does not account for the fact that the physical properties of machine-made snow (MM snow; Fierz et al. (2009)) differ from natural snow, and it would not be possible with the model to handle this information. Explicitly accounting for snow management techniques in snowpack models is something that has already been developed in a few cases. For example, Keller et al. (2004) used field observations of snow depth on groomed slopes to determine the compaction rate on a groomed ski slope. While this method may be informative in terms of processes occurring during the course of a simulated snow season, it depends on the weather conditions during this specific season and on local measurements. This hampers utilization on a large scale. Climate projection or the testing of various snow management policies are even more affected. Interdisciplinary programs recently combined physical snowpack models with detailed human approaches of snow management (Howard and Stull, 2014; Hanzer et al., 2014).

Nevertheless, the effects of snow management on snowpack properties are still rarely described in literature and only a few studies have reported detailed field observations (Keddy et al., 1979; Guily, 1991; Keller et al., 2004; Howard and Stull, 2014). In order to build a tool capable of addressing snow conditions on ski slopes for a wide range of resorts we have explicitly integrated comprehensive grooming and snowmaking approaches into the detailed multi-layer snowpack model Crocus (Vionnet et al., 2012). Grooming and snowmaking were implemented in Crocus 


\begin{tabular}{|c|c|c|c|c|c|}
\hline Resort & Lat. & Lon. & massif & $\begin{array}{c}\text { Altitude range } \\
\text { (m.a.s. })\end{array}$ & $\begin{array}{c}\text { Resort } \\
\text { Category }\end{array}$ \\
\hline Tignes & $45^{\circ} 26 \mathrm{~N}$ & $6^{\circ} 53 \mathrm{E}$ & Haute-Tarentaise & $1550-3456$ & Very Large \\
\hline Chamrousse & $45^{\circ} 6 \mathrm{~N}$ & $5^{\circ} 53 \mathrm{E}$ & Belledonne & $1400-2253$ & Large \\
\hline Autrans & $45^{\circ} 12 \mathrm{~N}$ & $5^{\circ} 33 \mathrm{E}$ & Vercors & $1000-1630$ & Nordic Ski \\
\hline Les 2 Alpes & $45^{\circ} 0 \mathrm{~N}$ & $6^{\circ} 7 \mathrm{E}$ & Oisans & $1300-3568$ & Very Large \\
\hline
\end{tabular}

TABLE 1: Main features of the four ski resorts where we carried out our 2014-2015 winter season field campaign. Resorts categories from François et al. (2014).

based on our physical comprehension of processes, literature and interviews with professionals. The latter were involved in our development strategy to represent their management practices in the most consistent way, which is critical for any further use of such a model. The model was evaluated with field measurements (depth, snow water equivalent and vertical profiles) carried out in four resorts in the French Alps during the 2014-2015 winter season. These measurements and the model implementation are described in an extensive manner including decision schemes and model parameterization. Instead of integrating in detail the specific snow management practices of one particular ski resort (Hanzer et al., 2014), this development aims to build a tool able to simulate the snow conditions for a wide range of resorts and geographical areas (François et al., 2014), and thus requires a rather generic formulation if possible. We tested the sensitivity of the model to the values of parameters and evaluated the results of simulations with respect to in-situ observations.

\section{MATERIAL AND METHODS}

\subsection{In-Situ observations}

Ski patrols from four specific resorts located in the Northern French Alps (Tignes, Chamrousse, Autrans and Les 2 Alpes) helped us to perform measurements during the 2014-2015 winter season (Table 1, Figure 1), covering a large range of meteorological conditions and operators' habits and means. 


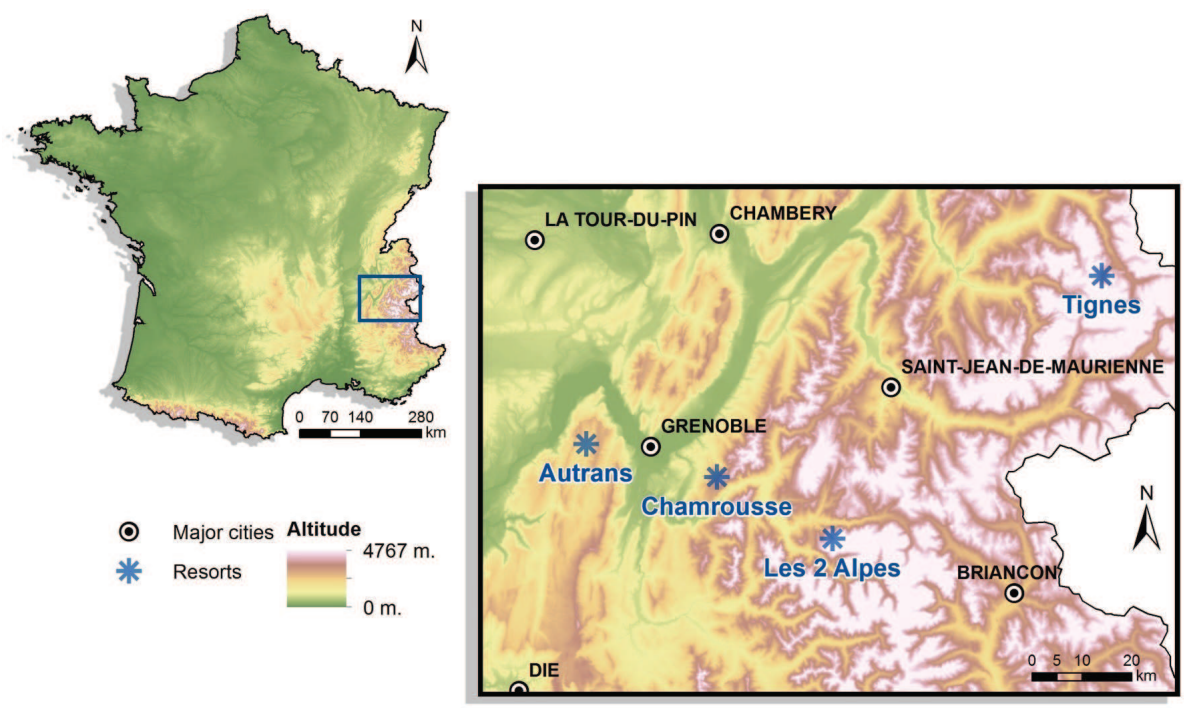

Figure 1: Location of the ski resorts around the city of Grenoble (France) : Tignes (HauteTarentaise), Chamrousse (Belledonne), Autrans (Vercors) and Les 2 Alpes (Oisans).

\subsubsection{Observations Sites}

Three observation sites with natural snow conditions (Reference site), grooming and packed and skied snow conditions (Site G) and grooming plus snowmaking and skiing (Site SM) were chosen in each resort with the aid of ski patrollers. All three sites within a given ski resort are located as closely as possible to each other and are easy to access. In every case local topography consists of flat or almost flat areas with as little wind disturbance as possible. None of the sites are in erosion or accumulation areas. However all sites are located in mountain areas where the wind may always play a significant role and be a factor of uncertainty.

\subsubsection{Snowmaking data on SM sites}

The most likely surface on which MM snow was spread $\left(S_{\text {mid }}\right)$ was calculated from ski slope edges, snow gun distribution on the ski slope, in-situ observations and interviews with professionals. For example in Tignes, snow guns are equally distributed on "Double M" ski slopes and the distance between them is $67 \mathrm{~m}$. The width of the site SM is $36 \mathrm{~m}$, resulting in a $2400 \mathrm{~m}^{2}$ surface. Assuming an 


\begin{tabular}{|c|c|c|c|c|c|c|c|c|c|}
\hline \multirow[t]{2}{*}{ Resort } & \multirow{2}{*}{$\begin{array}{c}\text { Total Water } \\
\text { Volume } \\
\left(\mathrm{m}^{3}\right)\end{array}$} & \multirow{2}{*}{$\begin{array}{c}\text { Observed Average } \\
\text { Water Flow } \\
\left(Q_{\mathrm{MM}}, \mathrm{m}^{3} \mathrm{~h}^{-1}\right)\end{array}$} & \multicolumn{4}{|c|}{ Distribution (\%) } & \multicolumn{3}{|c|}{$\begin{array}{l}\text { Snow Spreading } \\
\text { Surface }\left(\mathrm{m}^{2}\right)\end{array}$} \\
\hline & & & NOV & DEC & JAN & FEB & $S_{\min }$ & $S_{\text {mid }}$ & $S_{\max }$ \\
\hline Tignes & 2317 & $12.2(\mathrm{AW})$ & 29 & 71 & 0 & 0 & 2000 & 2400 & 2800 \\
\hline Chamrousse & 2322 & $15.6(F)$ & 0 & 100 & 0 & 0 & 3400 & 4250 & 5100 \\
\hline Autrans & 662 & $10.5(\mathrm{AW})$ & 0 & 100 & 0 & 0 & 1800 & 2400 & 3000 \\
\hline Les 2 Alpes & 6000 & $13.0(2 \times \mathrm{AW})$ & 25 & 33 & 33 & 9 & 6000 & 7500 & 8500 \\
\hline
\end{tabular}

TABLE 2: Snowmaking data for the 2014-2015 winter season for all four SM sites (snowguns data). $\mathrm{S}_{\min }, \mathrm{S}_{\text {mid }}, \mathrm{S}_{\max }$ are respectively the minimum, the most likely and the maximum surfaces on which MM snow was spread. "AW" stands for air-water gun and "F" for fan gun.

uncertainty of $\pm 400 \mathrm{~m}^{2}$ i.e. $\pm 17 \%$ on the surface (an uncertainty of about $8 \%$ concerning length and width), the resulting range on the surface is $S_{\min }=2000$ to $\mathrm{S}_{\max }=2800 \mathrm{~m}^{2}$ (the minimum and maximum surfaces on which MM snow could have been spread respectively). Similar treatments were applied in other resorts (Table 2).

The uncertainty on spreading surfaces is shown in figures (section 5) as an envelope (corresponding to simulations using $S_{\min }$ and $S_{\max }$ ) around the standard simulation (which uses $S_{\text {mid }}$ ).

\subsubsection{Measurements}

A measurement protocol was instigated in order to deliver a maximum amount of information within the available time and means.

- Snow depth (SD) was measured once a week by ski patrollers, on each site. Depending on local topography several measurements were made for each site so as to provide reliable integrated results as well as an indication of the deviation of measurements.

- The average density of the snowpack was measured once a month on each site. We used a Polar Ice Coring Office (PICO) lightweight coring auger (Koci and Kuivinen, 1984).

- The snow water equivalent of the snowpack was deduced from these observations, as the product of SD and average density .

- A complete stratigraphy of the main site SM with grooming and snowmaking 
was carried out every month. It included the measurement of snow layers specific surface areas (SSA), using the DUFISSS instrument (Gallet et al., 2009; Morin et al., 2013) and snow layers density (Fierz et al., 2009).

Average observations are displayed as dots on results figures (section 3, 4 and 5 ) with a surrounding envelope corresponding to \pm the standard deviation of the observations.

\subsection{SAFRAN - Crocus model chain}

\subsubsection{Snowpack Model}

The multilayer snowpack model SURFEX/ISBA-Crocus (hereafter, Crocus ; Vionnet et al. (2012)) explicitly solves the equations governing the energy and mass balance of the snowpack. This is done in a detailed manner which includes internal phenomena such as phase change, water percolation, snow compaction, snow metamorphism and information concerning their impact on the radiative and thermal properties of the snowpack. The energy budget of the snowpack is explicitly solved at its two interfaces (snow/atmosphere and snow/ground) and within the vertical profile. The snowpack is discretized within up to 50 numerical layers ensuring an appropriate description of the snowpack's internal processes. The model time step is $900 \mathrm{~s}$ (15 minutes). Microstructure properties of snow in Crocus can be described using the following variables :

- Density $(\rho)$ : the mass of a snow sample per unit volume (Vionnet et al., 2012);

- Specific surface area (SSA) : the total area at the ice/air interface in a snow sample per unit mass (Carmagnola et al., 2014);

- Sphericity (S) : the ratio between rounded versus angular shapes (Brun et al., 1992);

- Age : the time since snowfall, used to approximate the radiative impact of the deposition of light-absorbing impurities on the snow (Vionnet et al., 2012) snowpack properties (Figure 2), including grooming and snowmaking processes. 


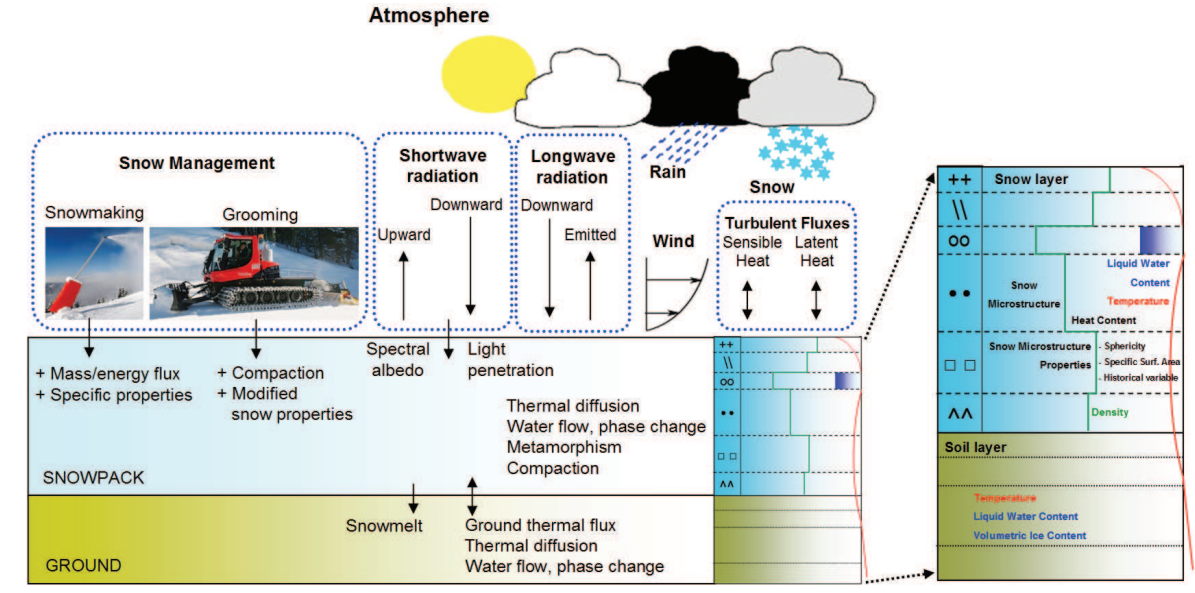

FIgURE 2: The SAFRAN-SURFEX/ISBA-Crocus scheme including grooming and snowmaking effects on snowpack physics, adapted from Vionnet et al. (2012).

\subsubsection{Meteorological Data}

In French mountain regions, Crocus is usually run using outputs of the meteorological downscaling and surface analysis tool SAFRAN (Durand et al., 1993). SAFRAN operates on a geographical scale on meteorologically homogeneous mountain ranges (referred to as "massifs") within which meteorological conditions are assumed to depend only on altitude and slope aspect. There is strong evidence from operational and research activities that the SAFRAN-Crocus model chain yields realistic results in French mountain regions in terms of integrated snow properties such as snow depth and snow water equivalent (Lafaysse et al., 2013). For a detailed review of know applications of SAFRAN-Crocus since its original development, please refer to Vionnet et al. (2012) and to the page "Crocus- Scientific applications" (www.cnrm-game.fr web site).

All simulations in this paper are based on meteorological forcing data from SAFRAN corresponding to each site (altitude, slope angle and aspect). We specifically analysed the natural snow conditions provided by SAFRAN-Crocus with in-situ observations on a local scale from ski patrollers and Automatic Weather Stations (wind, snow/rain altitude limit, precipitation amount). We fitted the SAFRAN meteorological forcing data to local conditions for each observation site. Precipitation 


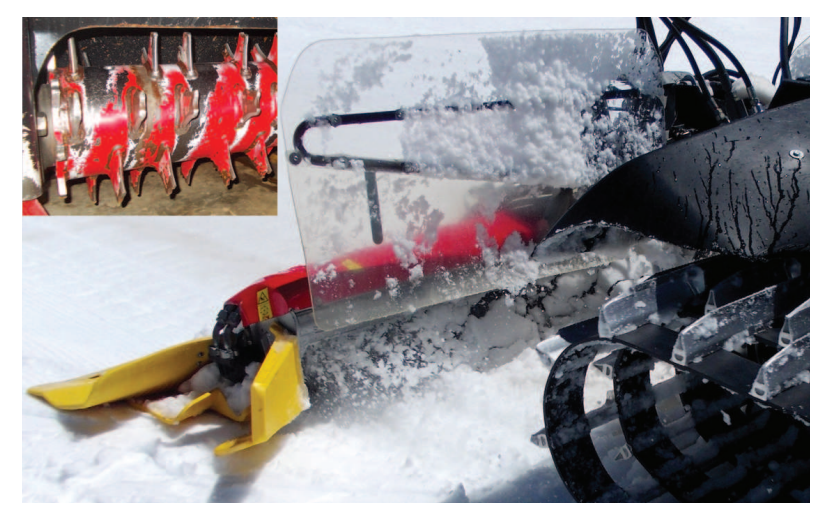

FiguRE 3: The tiller is mounted at the rear of a grooming machine and consists of a high speed rotating shaft (cutter bar) with multiple tines which acts as a mixer for the top of the snowpack

amount and phase were modified for several precipitation events on each site : Tignes (2 modified events), Chamrousse (4), Autrans (3) and Les 2 Alpes (6). All other meteorological variables remained unchanged.

We also took into account the surrounding slopes of each site and the consequent shadowing effect (Morin et al., 2012). We used a $25 \mathrm{~m}$ digital elevation model (Marcelpoil et al., 2012) to create a skyline profile : for each azimuth (steps of $\left.10^{\circ}\right)$, the elevation angle of the visible sky was calculated and checked with in-situ measurements.

\subsection{Grooming approach in the snowpack model}

Our approach to artificial snow grooming consists of both an extra static load applied on the snowpack and the additional effects of the tiller applied simultaneously.

\subsubsection{Static Stress}

The natural densification of the snowpack layers is mostly driven in the model by the weight of the top layers applied to those which are deeper (Vionnet et al., 2012). The static stress applied on the snowpack due to the weight of a grooming machine (ranging from 5 to $6 \mathrm{kPa}$ i.e. 500 to $600 \mathrm{~kg} \mathrm{~m}^{-2}$ ) is simply added to the weight of over burden layers (Guily, 1991; Olefs and Lehning, 2010; Howard and 


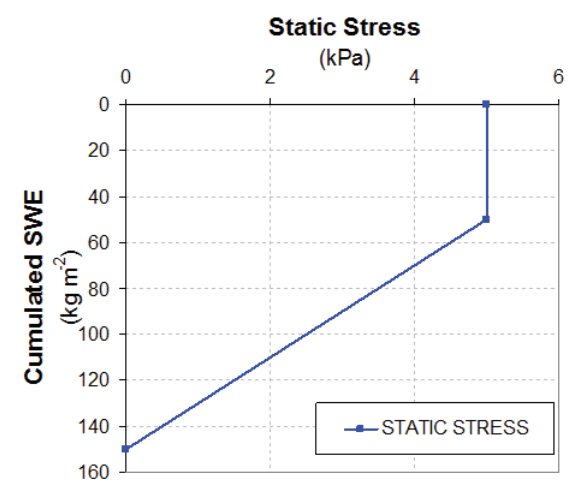

FIgURE 4: The static stress applied on snow layers in Crocus when grooming is carried out

Stull, 2014). The deeper the snowpack, the more dampened the load (Thumlert, 2013; Pytka, 2010). We consider here the cumulated snow water equivalent instead of snow depth to assess the stress applied on a layer. Indeed, SWE combines the density (Thumlert (2013) showed that the snowmobile stress penetration in the snowpack decreases with snow density) and depth of layers as the product of both. The resulting static stress (Figure 4$)$ is constant $(5 \mathrm{kPa})$ for the first $50 \mathrm{~kg} \mathrm{~m}^{-2}$ of snow e.g. the first $50 \mathrm{~cm}$ of fresh snow (density $100 \mathrm{~kg} \mathrm{~m}^{-3}$ ) or the first $10 \mathrm{~cm}$ of older snow (density $500 \mathrm{~kg} \mathrm{~m}^{-3}$ ). The stress then decreases linearly with increasing SWE until $150 \mathrm{~kg} \mathrm{~m}^{-2}$ of snow e.g. $1.5 \mathrm{~m}$ of fresh snow (density of $100 \mathrm{~kg} \mathrm{~m}^{-3}$ ) or $30 \mathrm{~cm}$ of older snow (density $500 \mathrm{~kg} \mathrm{~m}^{-3}$ ).

\subsubsection{Tiller effect}

The tiller is an additional tool mounted at the rear of a grooming machine and consists of a high speed rotating shaft (cutter bar) with multiple tines (Figure 3). Its action is basically to increase the density of the snow-by loading the snowpack with extra pressure-and to break down snow micro structure into rounded grains, which leads to higher density due to higher compacity (Fauve et al., 2002; Guily, 1991; Keddy et al., 1979). As a result, all impacted layers are mixed together, their properties are homogenized and some of them are modified. The effect of the tiller is simulated in Crocus by modifying the following properties of snow layers: 


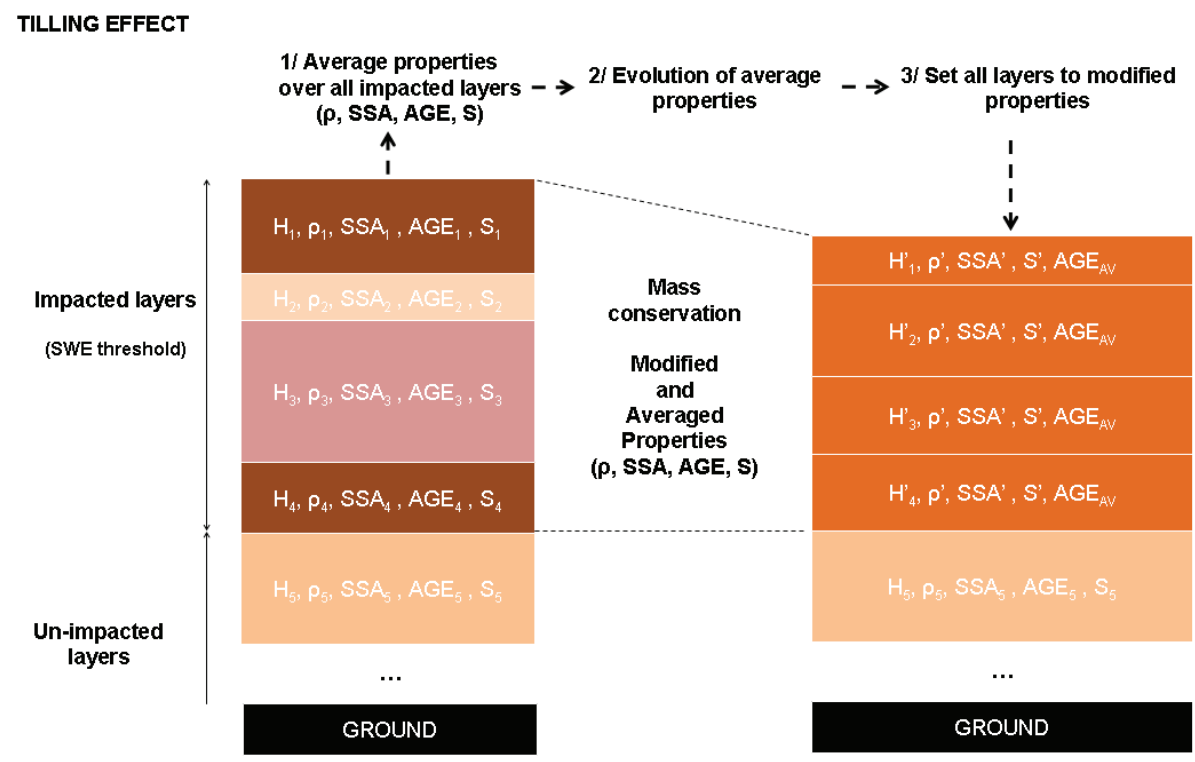

Figure 5: The tiller effect as implemented in Crocus

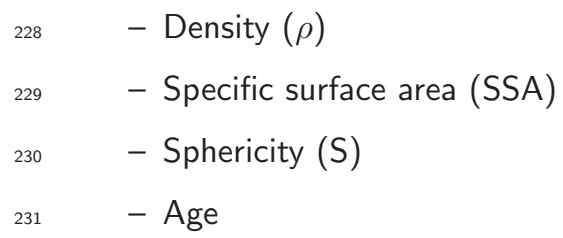

232 The tiller impacts the top layers of the snowpack within the top $35 \mathrm{~kg} \mathrm{~m}^{-2}$ of snow (according to the professionals) i.e. the top $35 \mathrm{~cm}$ of fresh snow (density 100 $\mathrm{kg} \mathrm{m}^{-3}$ ) or the top $7 \mathrm{~cm}$ of older snow (density $500 \mathrm{~kg} \mathrm{~m}^{-3}$ ). The sensitivity of the model to this value is tested in section 2.3.4. After each grooming session the evolved density $\rho_{\text {layer }}$ of impacted layers is given by :

$$
\rho_{\text {layer }}=M A X\left(\rho_{\mathrm{AV}} ; \frac{2 \rho_{\mathrm{AV}}+3 \rho_{\mathrm{t}}}{5}\right)
$$

Where $\rho_{\mathrm{AV}}$ is the weighted average density of impacted layers before grooming, using the SWE of each contributing layer, and $\rho_{\mathrm{t}}$ (Table 3$)$ is the target value the density may eventually reach through the grooming process (Fauve et al., 2002).

$$
\rho_{\mathrm{AV}}=\frac{\sum\left(\rho_{\text {layer }} * S W E_{\text {layer }}\right)}{\sum S W E_{\text {layer }}}
$$


This value $\rho_{\text {layer }}^{\prime}$ is attributed to every impacted layer, simulating the mixing and densification effects of the tiller. Unless snow becomes denser than the target value (for example through humidification), it gets infinitely closer to the target density $\rho_{\mathrm{t}}$, consistent with observations by Keddy et al. (1979) or Guily (1991) (Figure 6). If $\rho_{\mathrm{AV}}$ is already higher than $\rho_{\mathrm{t}}$, the model simulates a mixing effect without further densification. Eventually, the thickness of every snow layer is re-calculated with respect to the mass conservation of each layer :

$$
H_{\text {layer }}^{c}=H_{\text {layer }} * \frac{\rho_{\text {layer }}}{\rho_{\text {layer }}^{c}}
$$

The sphericity is treated in the same way (Figures 5). The average value of the age of snow layers is not modified, we simply attribute the average value (calculated similarly to $\rho_{\mathrm{AV}}$, simulating the mixing effect). The SSA of fresh snow is generally high and decreases with snow metamorphism (Domine et al., 2007), thus the grooming effect on SSA is

$$
S S A_{\text {layer }}=\operatorname{MIN}\left(S S A_{\mathrm{AV}} ; \frac{2 S S A_{\mathrm{AV}}+3 S S A_{\mathrm{t}}}{5}\right)
$$

The evolution of SSA, sphericity and density from equations 1 and 4 through five successive grooming sessions is shown in Figure 6 from two distinct initial values (one corresponds to relatively fresh snow while the other is more evolved snow). Observations from Keddy et al. (1979) or Guily (1991) show that after 5 grooming sessions, the average density of the snow is $450 \mathrm{~kg} \mathrm{~m}^{-3}$ and that snow microstructure turns to small rounded grains $(0.3 \mathrm{~mm})$. This corresponds to an SSA of $25 \mathrm{~m}^{2} \mathrm{~kg}^{-1}$ (Domine et al., 2007) and a sphericity of $90 \%$ (Brun et al., 1992). The resulting standard parameterization of the grooming model is :

- SWE of penetration (impacted layers) : $\mathrm{SWE}_{\mathrm{p}}=$ top $35 \mathrm{~kg} \mathrm{~m}^{-2}$

- Target density : $\rho_{\mathrm{t}}=450 \mathrm{~kg} \mathrm{~m}^{-3}$

- Target SSA : SSA $=25 \mathrm{~m}^{2} \mathrm{~kg}^{-1}$

- Target sphericity : $S_{t}=90 \%$

\subsubsection{Grooming schedule}

Figure 7 describes the decision scheme : whether or not to groom. Grooming is applied in Crocus if the following criteria are true : 

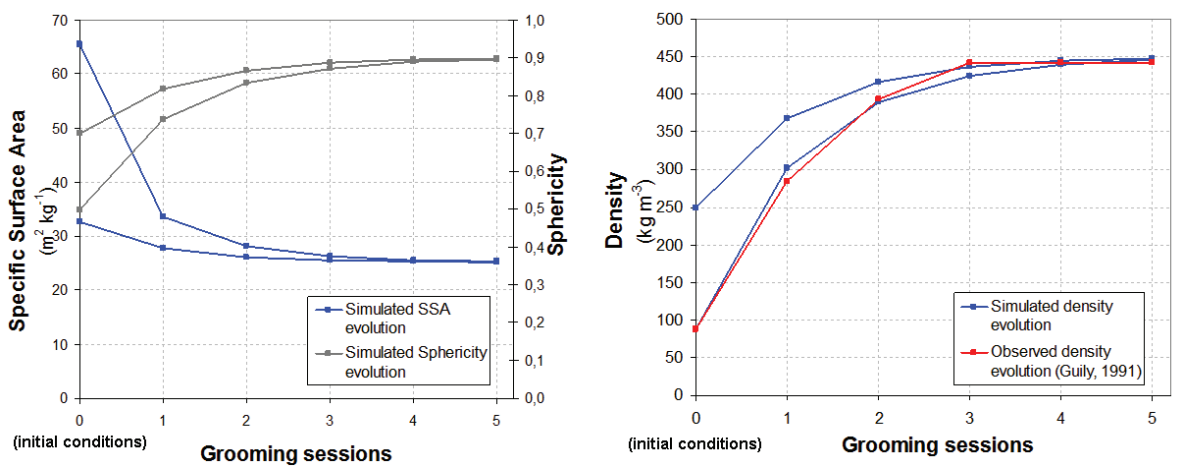

Figure 6: The evolution in Crocus of the specific surface area (SSA), sphericity (S) and density $(\rho)$ of impacted snow layers by the tiller after successive grooming sessions from different initial conditions. Once the target value is reached, the tiller still averages the impacted layers properties but no longer affects the average value. Only natural metamorphism (e.g. through humidification) can then increase the density and sphericity or decrease the SSA. This figure displays the evolution under the standard configuration when targets are set to $25 \mathrm{~m}^{2} \mathrm{~kg}^{-1}$ (SSA), 90\% (sphericity) and $450 \mathrm{~kg} \mathrm{~m}^{-3}$ (density).

- Grooming period : from November 1 until resort closing date.

- Enough snow to be groomed : a minimum value of $20 \mathrm{~kg} \mathrm{~m}^{-2}$ of SWE i.e. 20 $\mathrm{cm}$ of fresh snow (density of $100 \mathrm{~kg} \mathrm{~m}^{-3}$ ), otherwise grooming is impossible in the model.

- Working hour for grooming : 20:00 to 21:00 every day. In cases where it snows during the night, grooming is possible from 06:00 to 09:00 in the morning.

\subsubsection{Sensitivity test of the grooming model}

Seven configurations of the model parameterization are tested, combining three different levels of every parameter governing the penetration depth of the tiller $\left(\mathrm{SWE}_{\mathrm{p}}\right)$ and the impact on each snow layer (target values $\mathrm{S}_{\mathrm{t}}, \mathrm{SSA}_{\mathrm{t}}$ and $\rho_{\mathrm{t}}$ ). Table 3 contains the standard value (0) and the higher (1) and lower (-1) impact values on snow properties, for each parameter. All parameters are set to the standard value (0) while the (1) and (-1) levels are sequentially attributed to each of them (Table 4). Levels (-1) and (1) of $\mathrm{SSA}_{t}$ and $\mathrm{S}_{t}$ are attributed at the same time to the configurations G5 and G6 since SSA and sphericity can not be viewed as 


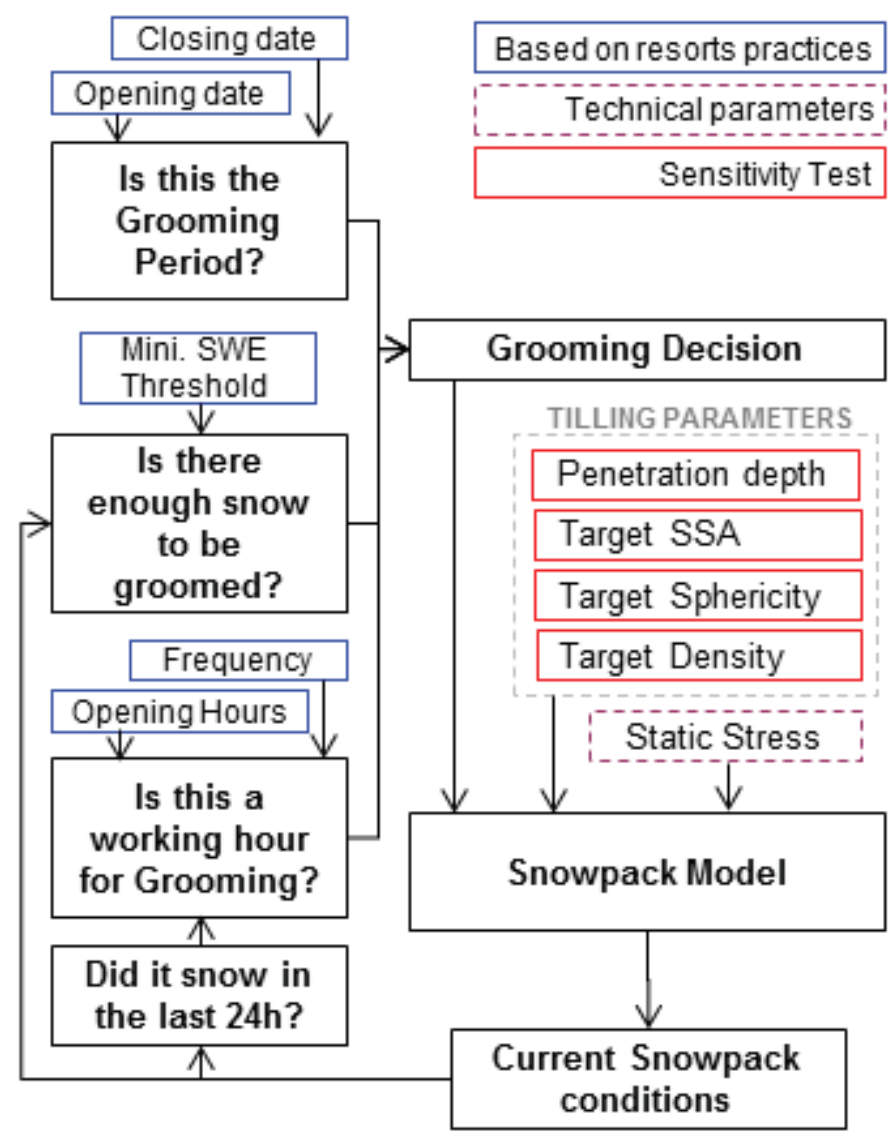

Figure 7: Grooming approach implemented in Crocus : decision scheme and main parameters

\begin{tabular}{|c|c|c|c|c|c|c|c|c|}
\hline \multirow{2}{*}{$\begin{array}{l}\text { Levels of } \\
\text { Parameters }\end{array}$} & \multicolumn{4}{|c|}{$\begin{array}{c}\text { Sensitivity test } \\
\text { Grooming parameterization }\end{array}$} & \multicolumn{4}{|c|}{$\begin{array}{c}\text { Sensitivity test } \\
\text { Snowmaking parameterization }\end{array}$} \\
\hline & $\begin{array}{c}\mathrm{SWE}_{\mathrm{p}} \\
\left(\mathrm{kg} \mathrm{m}^{-2}\right)\end{array}$ & $\begin{array}{l}\mathrm{S}_{\mathrm{t}} \\
(\%)\end{array}$ & $\begin{array}{c}\mathrm{SSA}_{\mathrm{t}} \\
\left(\mathrm{m}^{2} \mathrm{~kg}^{-1}\right)\end{array}$ & $\begin{array}{c}\rho_{\mathrm{t}} \\
\left(\mathrm{kg} \mathrm{m}^{-3}\right)\end{array}$ & $\begin{array}{c}\rho_{\mathrm{MM}} \\
\left(\mathrm{kg} \mathrm{m}^{-3}\right)\end{array}$ & $\begin{array}{c}\mathrm{SSA}_{\mathrm{MM}} \\
\left(\mathrm{m}^{2} \mathrm{~kg}^{-1}\right)\end{array}$ & $\begin{array}{l}\mathrm{S}_{\mathrm{MM}} \\
(\%)\end{array}$ & $\begin{array}{l}\mathrm{T}_{\mathrm{W}} \\
\left({ }^{\circ} \mathrm{C}\right)\end{array}$ \\
\hline 1 & 50 & 100 & 15 & 500 & 650 & 10 & 100 & -2 \\
\hline 0 & 35 & 90 & 25 & 450 & 600 & 22 & 90 & -4 \\
\hline-1 & 20 & 70 & 35 & 400 & 550 & 35 & 70 & -6 \\
\hline
\end{tabular}

TABLE 3: The different parameters and values used to test the sensitivity of the model to the parameterization of snow management processes. Level (1) and (-1) correspond respectively to a higher and lower impact (or metamorphism initial condition) on snow properties while (0) is the standard parameterization (section 2.3.2 and 2.4.3). The different combinations of these levels of parameters are specified in Table 4. 


\begin{tabular}{|c|c|c|c|c|c|c|c|c|c|c|c|c|c|c|c|}
\hline \multicolumn{9}{|c|}{ Sensitivity test } & \multicolumn{7}{c|}{ Sensitivity test } \\
Configuration & $\mathrm{G} 0$ & $\mathrm{G} 1$ & $\mathrm{G} 2$ & $\mathrm{G} 3$ & $\mathrm{G} 4$ & $\mathrm{G} 5$ & $\mathrm{G} 6$ & Configuration & $\mathrm{S} 0$ & $\mathrm{~S} 1$ & $\mathrm{~S} 2$ & $\mathrm{~S} 3$ & $\mathrm{~S} 4$ & $\mathrm{~S} 5$ & $\mathrm{~S} 6$ \\
\hline $\mathrm{SWE}_{\mathrm{p}}$ & 0 & -1 & 1 & 0 & 0 & 0 & 0 & $\rho_{\mathrm{MM}}$ & 0 & -1 & 1 & 0 & 0 & 0 & 0 \\
\hline$\rho_{\mathrm{t}}$ & 0 & 0 & 0 & -1 & 1 & 0 & 0 & $\mathrm{SSA}_{\mathrm{MM}}$ & 0 & 0 & 0 & -1 & 1 & 0 & 0 \\
\hline $\mathrm{S}_{\mathrm{t}}$ & 0 & 0 & 0 & 0 & 0 & -1 & 1 & $\mathrm{~S}_{\mathrm{MM}}$ & 0 & 0 & 0 & -1 & 1 & 0 & 0 \\
\hline $\mathrm{SSA}_{\mathrm{t}}$ & 0 & 0 & 0 & 0 & 0 & -1 & 1 & $\mathrm{~T}_{\mathrm{W}}$ & 0 & 0 & 0 & 0 & 0 & -1 & 1 \\
\hline
\end{tabular}

TABLE 4: Levels of parameters used for different combinations to test the sensitivity of the model to the values of parameters. The values of parameters corresponding to levels $(1),(-1)$ and $(0)$ are specified in Table 3. The configurations G0 and S0 are the standard parameterizations.

independent properties

- G5 : relatively angular snow microstructure with a small grain size $\left(\mathrm{SSA}_{\mathrm{t}}=\right.$ $35 \mathrm{~m}^{2} \mathrm{~kg}^{-1}$ and $\mathrm{S}_{\mathrm{t}}=70 \%$ )

- G6 : rather spherical snow microstructure with a larger grain size $\left(\mathrm{SSA}_{\mathrm{t}}=15\right.$ $\mathrm{m}^{2} \mathrm{~kg}^{-1}$ and $\mathrm{S}_{\mathrm{t}}=100 \%$ )

\subsection{Snowmaking approach in the snowpack model}

Here we describe the snowmaking approach we implemented in the model. In order to focus on the representation of the physical processes in the model, we collected relevant data at the four observation sites (Table 2) and used it as input to produce snow in the model. We collected the season's total water volume used for snowmaking (TWV) and its monthly distribution at each site (Table 2) which we implemented as the target production in Crocus (Figure 8). For example in Tignes, $29 \%$ of the TWV (2317 $\mathrm{m}^{3}$, Table 2) was used in November (i.e. $672 \mathrm{~m}^{3}$ ) and was spread over 2000 (minimum) to $2800 \mathrm{~m}^{2}$ (maximum, Table 2), resulting in a target production of $240 \mathrm{~kg} \mathrm{~m}^{-2}$ (simulation with the minimum MM snow) to 336 $\mathrm{kg} \mathrm{m}^{-2}$ (simulation with the maximum MM snow). An efficiency ratio is further applied on these amounts (Section 2.4.4).

\subsubsection{Production decisions}

Beyond the quantity of MM snow, the production decision is further dictated by simple rules (Figure 8), based on interviews with snowmakers and literature 


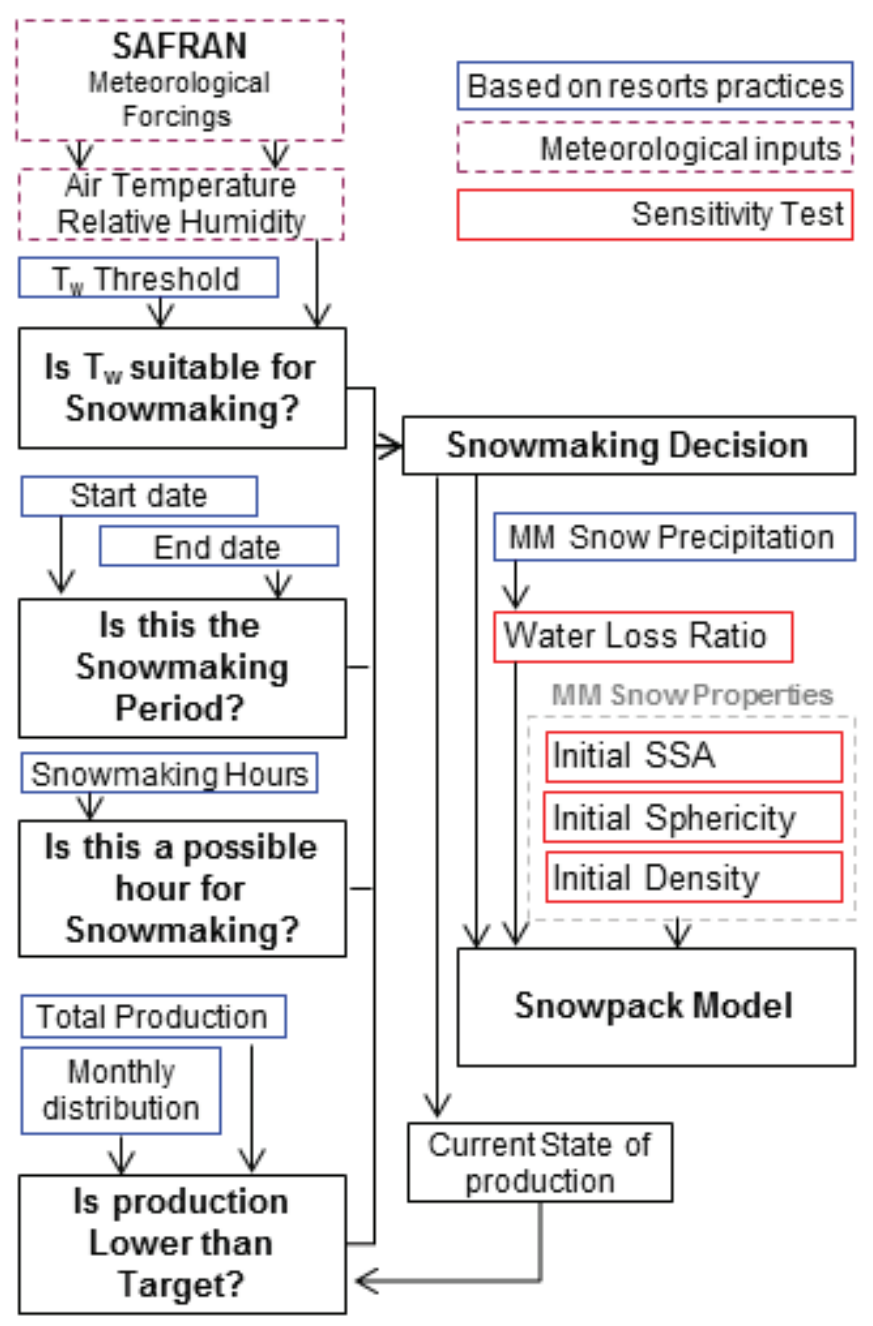

FiguRE 8: Snowmaking approach implemented in Crocus : decision scheme and main parameters (see text for details). 
(Hanzer et al., 2014; Marke et al., 2014). Production is possible from November 1 until March 31. No production is allowed from 08:00 to 19:00 (opening hours). Every evening (19:00) the cumulated snow production is compared with the target. If current production is deficient then production is possible until the next morning, mimicking field practices where snowmaking facilities are generally run for the entire night rather than turned on for only a few hours. Wind speed should not exceed 4.2 $\mathrm{m} \mathrm{s}^{-1}\left(15 \mathrm{~km} \mathrm{~h}^{-1}\right)$ for snow production (commonly admitted threshold). Lastly, a wet-bulb temperature $\left(T_{W}\right)$ threshold is used to dictate whether or not snowmaking is triggered.

\subsubsection{Wet-bulb temperature calculation}

The wet-bulb temperature is argued to be the most relevant criterion to determine whether or not snowmaking is possible. (Olefs et al., 2010). For convenient calculation in the model, we used the explicit method from Jensen et al. (1990) to compute $T_{W}$ from the SAFRAN dry air temperature and humidity (Spandre et al., 2014). This explicit method provides consistent values of wet-bulb temperature within the range of -15 to $0^{\circ} \mathrm{C}$ for the dry air temperature and from 30 to $100 \%$ for the relative humidity : the maximum error compared to Olefs et al. (2010) implicit method is $\pm 0.3^{\circ} \mathrm{C}$ (Olefs et al., 2010).

\subsubsection{Machine made snow initial properties}

MM snow is assumed to be small rounded grains (about $0.3 \mathrm{~mm}$ ), falling with a density $\rho_{\mathrm{MM}}=600 \mathrm{~kg} \mathrm{~m}^{-3}$, a $\mathrm{SSA}_{\mathrm{MM}}=22 \mathrm{~m}^{2} \mathrm{~kg}^{-1}$ (Domine et al., 2007) and a sphericity $\mathrm{S}_{\mathrm{MM}}=90 \%$ (Fauve et al., 2002; Brun et al., 1992), accounting for the spherical nature of MM snow crystals (Table 3). If some natural snow falls during snowmaking, the incoming mass rate is summed with the MM snow production mass rate. The physical properties of the snowfall are then calculated from the properties of the natural snow (Vionnet et al., 2012) and the MM snow initial properties, weighted by the incoming mass rates. 

$353 \quad 3$ and 4).

\subsubsection{Snowmaking efficiency and rate}

Snowmaking efficiency. The mass yield of snowmaking differs from unity, because of various effects including sublimation (Eisel et al., 1988) and transport by wind (Olefs et al., 2010). Eisel et al. (1988) found 2 to $13 \%$ water loss without accounting for wind drift while Olefs et al. (2010) mentioned a 5 to $40 \%$ total water loss. The proportion of water loss is uncertain and as far as we know no extensive field measurements were reported in the literature. Four levels of the efficiency ratio R, ranging from $100 \%$ (no water loss) to $25 \%$ (i.e. $75 \%$ of water loss) are considered here. The grooming only simulation (no production) is the case when the efficiency is $\mathrm{R}=0 \%$. Unless specified, all simulations with snowmaking use a ratio $\mathrm{R}=50 \%$ (standard value).

Production rate. The $\mathrm{MM}$ snow precipitation rate $\left(\mathrm{P}_{\mathrm{MM}}, \mathrm{kg} \mathrm{m}^{-2} \mathrm{~s}^{-1}\right)$ was set at a constant value in the model on each site (Figure 8) and was calculated as the multiplication of the season's observed average water flow on the site $\left(Q_{M M}\right.$ in $\mathrm{kg}$ $\mathrm{s}^{-1}$, Table 2) and the water loss ratio $\mathrm{R}$, divided by the spreading surface of the site $\left(S_{\text {mid }}\right.$ in $\mathrm{m}^{2}$, Table 2$)$.

$$
\mathrm{P}_{\mathrm{MM}}(\text { site })=\frac{\mathrm{Q}_{\mathrm{MM}}(\text { site }) * \mathrm{R}}{\mathrm{S}_{\text {mid }}(\text { site })}
$$

\subsubsection{Snowmaking model sensitivity test}

Seven configurations (Table 3 and 4) were used to test the sensitivity of the snowmaking model to the parameterization for the MM snow density $\left(\rho_{\mathrm{MM}}\right)$, specific surface area $\left(S_{S} A_{M M}\right)$ and sphericity $\left(S_{M M}\right)$ and the wet-bulb temperature threshold which triggers snowmaking $\left(T_{W}\right)$. A sensitivity test of the efficiency coefficient $\mathrm{R}$ (ranging from $\mathrm{R}=100 \%$ to $25 \%$ ) was performed separately, using the standard configuration of the grooming and snowmaking model. All simulations with snowmaking use the standard parameterization of the grooming model (G0, Table 


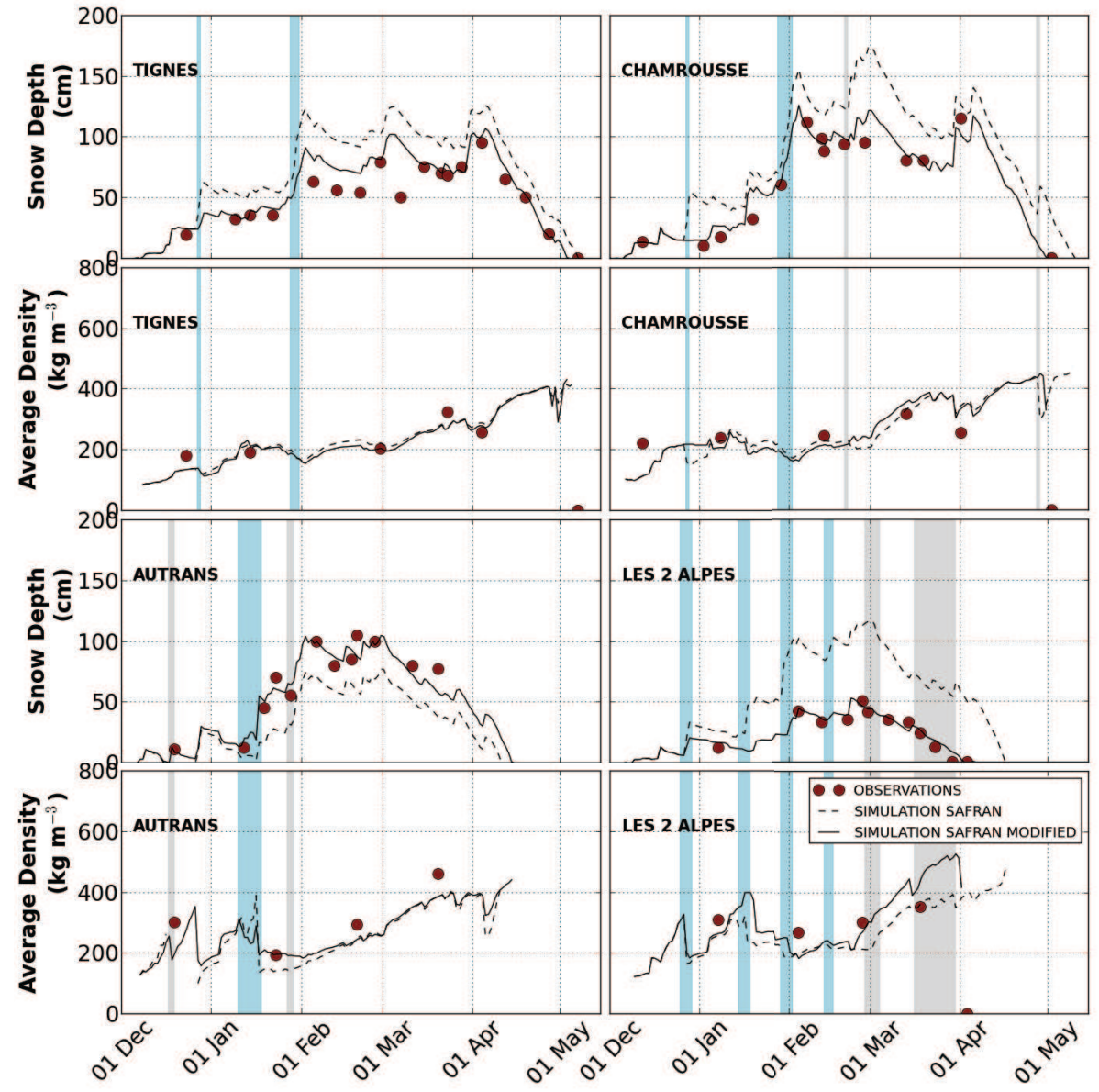

Figure 9: Natural snow depth and snowpack average density with respect to in-situ observations (Natural snow site). Runs using SAFRAN forcing data and modified SAFRAN forcing data are shown (Section 2.2.2). The colour blue shows events when the precipitation amount was modified (due to wind drift or mis-estimation of the precipitation amount by the model) while the colour grey shows events when the phase of precipitation (snow/rain) was modified. 


\begin{tabular}{|c|c|c|c|c|c|c|c|c|c|c|c|c|}
\hline Resort & \multicolumn{4}{|c|}{ Tignes } & \multicolumn{3}{c|}{ Chamrousse } & \multicolumn{3}{c|}{ Autrans } & \multicolumn{3}{c|}{ Les 2 Alpes } \\
\hline Run & $\begin{array}{c}\text { SD } \\
(\mathrm{cm})\end{array}$ & $\begin{array}{c}\text { SWE } \\
\left(\mathrm{kg} \mathrm{m}^{-2}\right)\end{array}$ & $\begin{array}{c}\text { Density } \\
\left(\mathrm{kg} \mathrm{m}^{-3}\right)\end{array}$ & $\begin{array}{c}\text { SD } \\
(\mathrm{cm})\end{array}$ & $\begin{array}{c}\text { SWE } \\
\left(\mathrm{kg} \mathrm{m}^{-2}\right)\end{array}$ & $\begin{array}{c}\text { Density } \\
\left(\mathrm{kg} \mathrm{m}^{-3}\right)\end{array}$ & $\begin{array}{c}\text { SD } \\
(\mathrm{cm})\end{array}$ & $\begin{array}{c}\text { SWE } \\
\left(\mathrm{kg} \mathrm{m}^{-2}\right)\end{array}$ & $\begin{array}{c}\text { Density } \\
\left(\mathrm{kg} \mathrm{m}^{-3}\right)\end{array}$ & $\begin{array}{c}\text { SD } \\
(\mathrm{cm})\end{array}$ & $\begin{array}{c}\text { SWE } \\
\left(\mathrm{kg} \mathrm{m}^{-2}\right)\end{array}$ & $\begin{array}{c}\text { Density } \\
\left(\mathrm{kg} \mathrm{m}^{-3}\right)\end{array}$ \\
\hline Nb. of Observations & 18 & 6 & 6 & 14 & 6 & 6 & 12 & 4 & 4 & 12 & 5 & 5 \\
\hline SAFRAN & 30 & 60 & 31 & 33 & 108 & 181 & 27 & 141 & 47 & 54 & 131 & 188 \\
\hline SAFRAN MODIFIED & 14 & 19 & 30 & 10 & 30 & 59 & 8 & 81 & 66 & 5 & 23 & 61 \\
\hline
\end{tabular}

TABLE 5: RMSD of simulated natural snow conditions with respect to in-situ observations (natural snow site) for snow depth (SD), snow water equivalent (SWE) and density. We display the results of runs using SAFRAN forcing data and modified SAFRAN forcing data with daily observations (wind, precipitation, temperature) close to the study area.

\section{Natural Snow : observations and simulation results}

Observations. By December 1st, none of the observation sites had natural snow cover yet (due to relatively dry and warm conditions in the early season, Figure 9). Significant snowfall occurred during the Christmas holidays and in January, within short periods of intense precipitation. The wind significantly eroded this natural snow on several occasions.

Natural snow conditions simulated by SAFRAN-Crocus are shown in Figure 9 along with in-situ observations (snow depth and average density). SAFRAN forcing data and modified SAFRAN forcing data (Section 2.2.2) were used. Table 5 contains the calculated Root Mean Square Deviation (RMSD) of these two runs with respect to the mean of the observations. The modified forcing data improves SAFRANCrocus accuracy, particularly when the snowpack is very thin (e.g. in Les 2 Alpes). SAFRAN-Crocus provides realistic results for the snow depth (SD), snow water equivalent (SWE) and average density with errors similar to Essery et al. (2013) : about $30 \mathrm{~kg} \mathrm{~m}^{-2}$ for SWE and $10 \mathrm{~cm}$ for SD. Simulations investigating grooming or snowmaking effects on the snowpack were systematically forced by the modified SAFRAN meteorological data.

\section{Grooming : observations and simulation results}

No observation sites with groomed ski slopes only (sites G) were opened to skiers during the Christmas holidays. Groomed snowpack conditions simulated by Crocus are shown in Figure 10 along with in-situ observations (snow depth and 
average density). All seven configurations of the sensitivity test (Table 3 and 4) are shown as well as the simulation using the static load alone (no tilling effect) and the natural snow simulation. The grooming model yields more realistic simulations of the average density of the groomed slopes than the natural simulation (Table 6). The grooming model is also closer to observations than the static load simulation. Grooming significantly enhanced the snowpack density (Figure 10) and made the average density steadier than in natural snow conditions, ranging between 400 to $500 \mathrm{~kg} \mathrm{~m}^{-3}$. However, regarding the deviation of all grooming configurations and the uncertainty of the observations, it is impossible to conclude which configuration provides better results.

The simulated profile of the top $30 \mathrm{~cm}$ of the snowpack (Site SM) from January 2015 until the end of the observation campaign is shown in Figure 11. On these dates and within the top $30 \mathrm{~cm}$, we assume that there is no MM snow which is located more deeply in the snowpack from early January (section 5). The impact of grooming on natural snow can be observed with all seven simulation profiles : (Table 3 and 4), the static load alone, the natural simulation and the observations. The greater homogeneity of groomed layers with respect to natural snow layers appears very clearly for both SSA and density profiles. The density values calculated by the grooming model are very consistent with observations.

The model is proven to provide realistic simulations of groomed snowpack conditions and we believe it could now be used to investigate the snowpack internal physical processes which occur when grooming natural snow.

\section{Snowmaking : observations, simulations and discussions}

\subsection{Evaluation of wet-bulb temperature $\left(T_{\mathrm{W}}\right)$ calculation}

Observations and simulations. The wet-bulb temperature calculated with the dry air temperature and relative humidity from SAFRAN was compared with local measurements by snow gun sensors (Figure 12). We limited the period (December 1st to February 17th) to the longest time for which sensor data were available in all three resorts (Autrans could not provide these data for technical reasons). A detailed ana- 


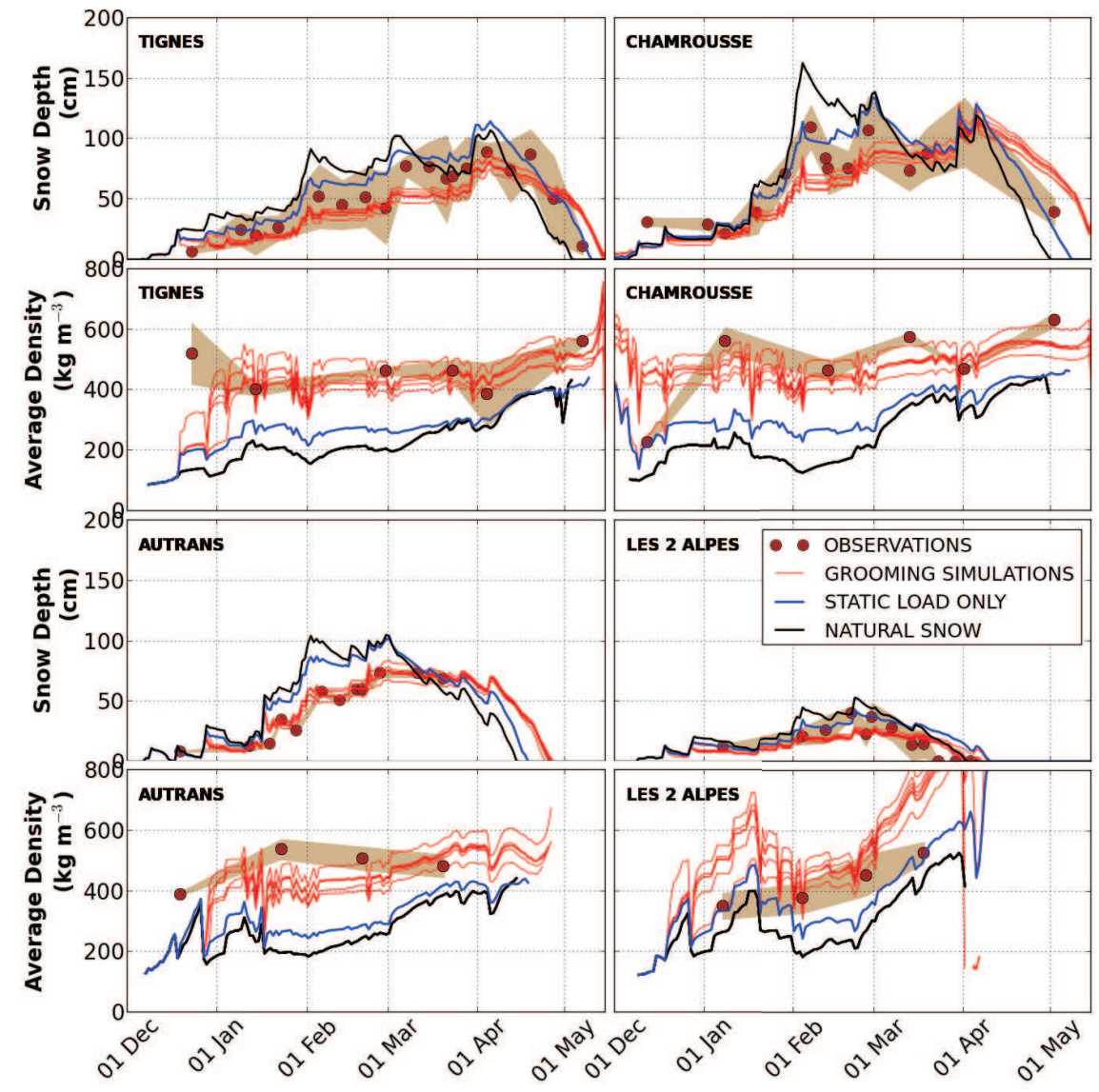

Figure 10: Grooming impact on snowpack properties (snow depth, average density). All seven configurations of the sensitivity test (Table 3 and 4 ) are shown as well as the simulation using the static load alone (no tilling effect) and the natural snow simulation. The brown envelope corresponds to \pm the standard deviation of observations around the average value. 

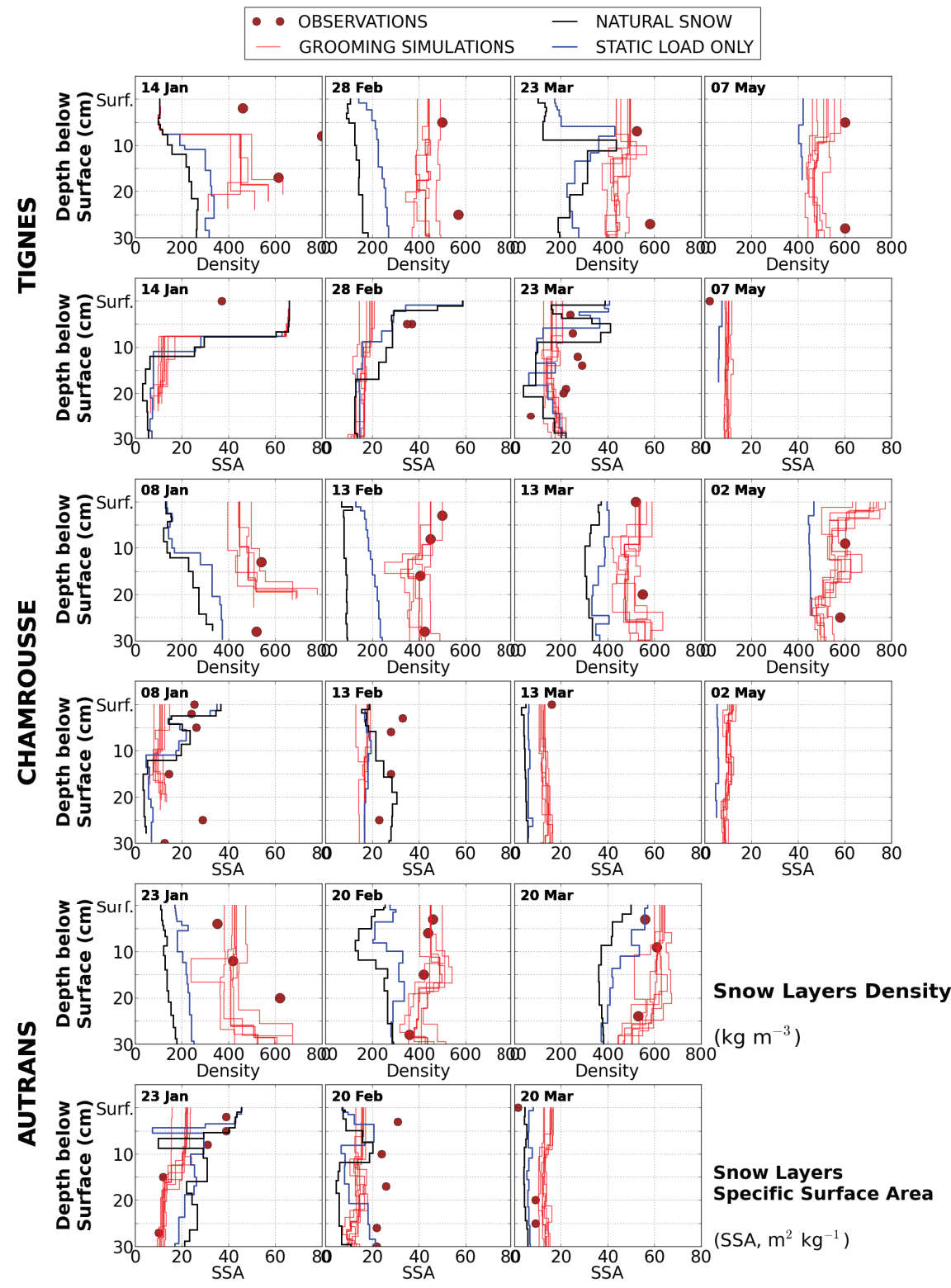

FIGURE 11: Impact of grooming on SSA and density profiles within the top $30 \mathrm{~cm}$ of the snowpack. All seven configurations of the sensitivity test (Table 3 and 4 ) are shown as well as the simulation using the static load alone (no tilling effect) and the natural snow simulation. The natural snow curve does not appear in May since there is no RBore snow on these dates. 


\begin{tabular}{|c|c|c|c|c|c|c|c|c|c|c|c|c|}
\hline Resort & \multicolumn{4}{|c|}{ Tignes } & \multicolumn{3}{c|}{ Chamrousse } & \multicolumn{3}{c|}{ Autrans } & \multicolumn{3}{c|}{ Les 2 Alpes } \\
\hline RMSD & $\begin{array}{c}\text { SD } \\
(\mathrm{cm})\end{array}$ & $\begin{array}{c}\text { SWE } \\
\left(\mathrm{kg} \mathrm{m}^{-2}\right)\end{array}$ & $\begin{array}{c}\text { Density } \\
\left(\mathrm{kg} \mathrm{m}^{-3}\right)\end{array}$ & $\begin{array}{c}\text { SD } \\
(\mathrm{cm})\end{array}$ & $\begin{array}{c}\text { SWE } \\
\left(\mathrm{kg} \mathrm{m}^{-2}\right)\end{array}$ & $\begin{array}{c}\text { Density } \\
\left(\mathrm{kg} \mathrm{m}^{-3}\right)\end{array}$ & $\begin{array}{c}\text { SD } \\
(\mathrm{cm})\end{array}$ & $\begin{array}{c}\text { SWE } \\
\left(\mathrm{kg} \mathrm{m}^{-2}\right)\end{array}$ & $\begin{array}{c}\text { Density } \\
\left(\mathrm{kg} \mathrm{m}^{-3}\right)\end{array}$ & $\begin{array}{c}\text { SD } \\
\left(\mathrm{cm}^{2}\right)\end{array}$ & $\begin{array}{c}\text { SWE } \\
\left(\mathrm{kg} \mathrm{m}^{-2}\right)\end{array}$ & $\begin{array}{c}\text { Density } \\
\left(\mathrm{kg} \mathrm{m}^{-3}\right)\end{array}$ \\
\hline Nb. of obs. & 18 & 6 & 6 & 14 & 6 & 6 & 12 & 4 & 4 & 12 & 5 & 5 \\
\hline Std. dev. of obs. & 21 & 94 & 61 & 17 & 92 & 25 & 4 & 41 & 31 & 8 & 41 & 44 \\
\hline Natural Snow & 21 & 60 & 243 & 29 & 147 & 244 & 27 & 80 & 239 & 13 & 19 & 145 \\
\hline Static Load Only & 14 & 31 & 190 & 16 & 81 & 181 & 21 & 49 & 195 & 13 & 43 & 308 \\
\hline Grooming std. conf. (G0) & 15 & 63 & 128 & 20 & 70 & 110 & 5 & 36 & 103 & 9 & 32 & 149 \\
\hline
\end{tabular}

TABLE 6: RMSD of simulated groomed snowpack conditions (Grooming standard configuration G0, see section 2.3.2, Table 3 and 4) with respect to in-situ observations (Site G) for snow depth (SD), snow water equivalent (SWE) and density. The standard deviation of observations was calculated for each day and the average standard deviation over the season is contained in the line 'Std. dev. of obs.'

lysis of $T_{W}$ during this period showed that the measured $T_{W}$ by snow gun sensors was 1 to $2{ }^{\circ} \mathrm{C}$ warmer than $T_{W}$ calculated from SAFRAN data (data not shown, consistent with Figure 12). The cumulated time for low wet-bulb temperatures ( $<$ $-6^{\circ} \mathrm{C}$ ) was higher with $T_{W}$ calculated from SAFRAN data. The cumulated time for $\mathrm{T}_{\mathrm{W}}$ below $-10^{\circ} \mathrm{C}$ was very low when based on measured $\mathrm{T}_{\mathrm{W}}$.

Discussion. Even though these errors are significant, such differences have already been observed (Huwald et al., 2009) and are probably related in a large extent to the sensors themselves, warmer during the day when heated by solar radiation due to insufficient sheltering. Data from automatic weather stations of the official meteorological observation service (thus more protected from such sensor measurement issues) show a better agreement with data from SAFRAN than from snow gun sensors (data not shown). However, we consider that the agreement between measured and simulated $T_{W}$ fulfils our expectations, i.e. to simulate snowmaking decisions in a realistic and reasonable manner.

\subsection{Snowmaking impact on snowpack properties}

Observations. All ski slopes including snowmaking (sites SM) were open to skiers for the Christmas holidays, despite unfavourable snow and meteorological conditions. Most of the total production capacity was consumed by late December : Tignes, Chamrousse and Autrans did not produce MM snow after January 1st. 


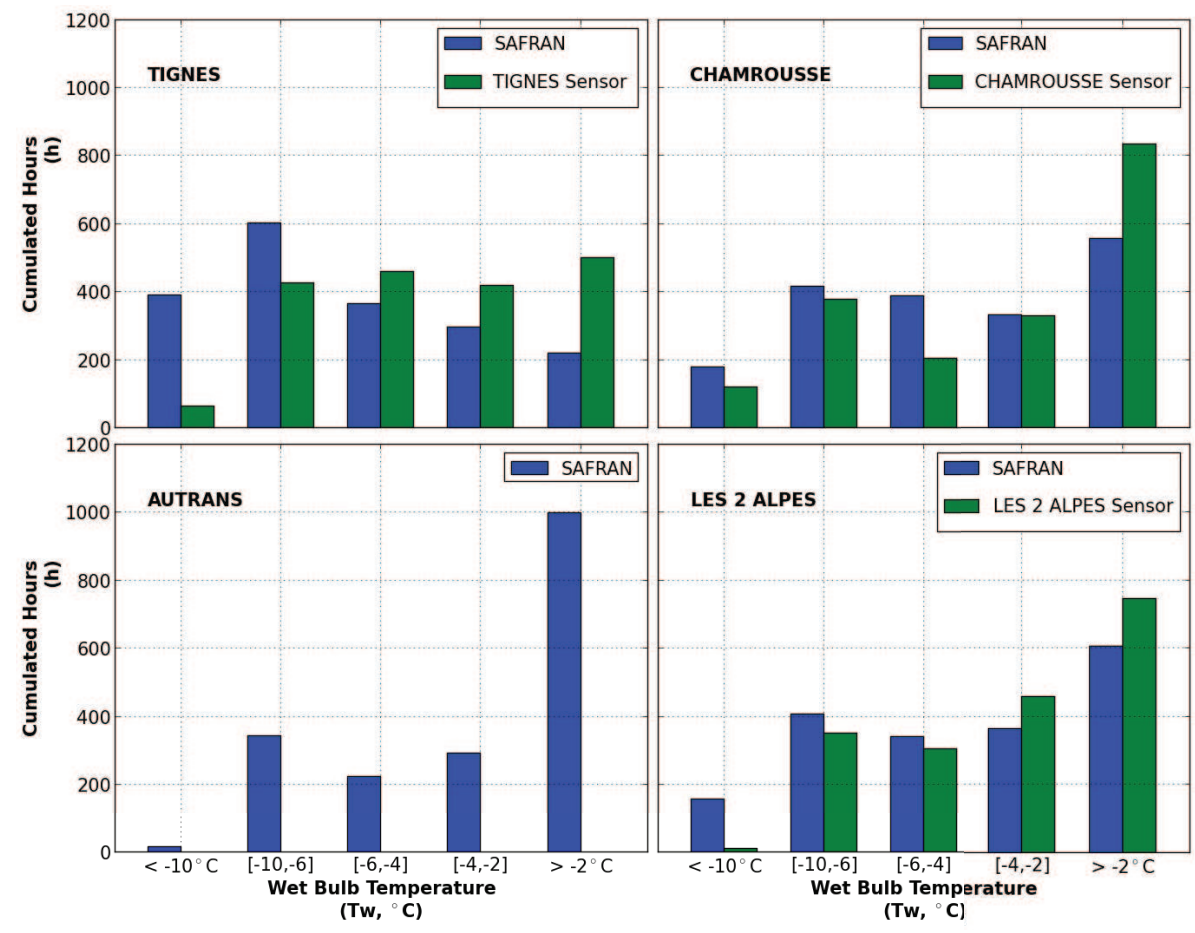

Figure 12: Cumulated hours when wet-bulb temperature falls between specified thresholds from December 1 st to February 17th. This was the longest period for which sensor data were available in all three resorts together: Tignes, Chamrousse and Les 2 Alpes. Sensor data were not available for Autrans. Calculations from SAFRAN data and the formulation by Jensen et al. (1990) are also shown for each site.

\begin{tabular}{|c|c|c|c|c|c|}
\hline & $\begin{array}{c}\text { Simulated } \\
\text { Production time } \\
(\mathrm{h})\end{array}$ & $\begin{array}{c}\text { Observed } \\
\text { Production time } \\
(\mathrm{h})\end{array}$ & $\begin{array}{c}\text { Simulated } \\
\text { Average } \mathrm{T}_{\mathrm{W}} \\
\left({ }^{\circ} \mathrm{C}\right)\end{array}$ & $\begin{array}{c}\text { Observed } \\
\text { Average water flow } \\
\left(\text { Table 2, } \mathrm{m}^{3} \mathrm{~h}^{-1}\right)\end{array}$ & $\begin{array}{c}\text { Average water flow }\left(\mathrm{m}^{3} \mathrm{~h}^{-1}\right) \\
\text { by means of the equations } \\
\text { by Olefs et al. }(2010)\end{array}$ \\
\hline Tignes & 195 & 190 & -6.5 & 12.2 & 8.6 \\
\hline Chamrousse & 157 & 149 & -7.6 & 15.6 & 16.3 \\
\hline Autrans & 65 & 63 & -6.4 & 10.5 & 8.4 \\
\hline Les 2 Alpes & 242 & 230 & -6.6 & 13.0 & 8.7 \\
\hline
\end{tabular}

TABLE 7: Simulated production time and average $T_{W}$ (when production occurred) using the standard configuration of the model (Section 2.4.3, Table 3 and 4) over the 2014-2015 winter season. The observed production time and the average water flow across the season are also shown. The average water flow was calculated by means of the equations of Olefs et al. (2010) with respect to the average $T_{W}$ when production occurred. 


\begin{tabular}{|c|c|c|c|c|c|c|c|c|c|c|c|c|}
\hline Resort & \multicolumn{4}{|c|}{ Tignes } & \multicolumn{3}{c|}{ Chamrousse } & \multicolumn{3}{c|}{ Autrans } & \multicolumn{3}{c|}{ Les 2 Alpes } \\
\hline RMSD & $\begin{array}{c}\text { SD } \\
(\mathrm{cm})\end{array}$ & $\begin{array}{c}\text { SWE } \\
\left(\mathrm{kg} \mathrm{m}^{-2}\right)\end{array}$ & $\begin{array}{c}\text { Density } \\
\left(\mathrm{kg} \mathrm{m}^{-3}\right)\end{array}$ & $\begin{array}{c}\text { SD } \\
(\mathrm{cm})\end{array}$ & $\begin{array}{c}\text { SWE } \\
\left(\mathrm{kg} \mathrm{m}^{-2}\right)\end{array}$ & $\begin{array}{c}\text { Density } \\
\left(\mathrm{kg} \mathrm{m}^{-3}\right)\end{array}$ & $\begin{array}{c}\text { SD } \\
(\mathrm{cm})\end{array}$ & $\begin{array}{c}\text { SWE } \\
\left(\mathrm{kg} \mathrm{m}^{-2}\right)\end{array}$ & $\begin{array}{c}\text { Density } \\
\left(\mathrm{kg} \mathrm{m}^{-3}\right)\end{array}$ & $\begin{array}{c}\text { SD } \\
\left(\mathrm{cm}^{2}\right.\end{array}$ & $\begin{array}{c}\text { SWE } \\
\left(\mathrm{kg} \mathrm{m}^{-2}\right)\end{array}$ & $\begin{array}{c}\text { Density } \\
\left(\mathrm{kg} \mathrm{m}^{-3}\right)\end{array}$ \\
\hline Nb. of obs. & 18 & 6 & 6 & 14 & 6 & 6 & 12 & 4 & 4 & 12 & 5 & 5 \\
\hline Std. dev. of obs. & 21 & 167 & 38 & 17 & 59 & 28 & 4 & 46 & 54 & 8 & 154 & 44 \\
\hline Natural Snow & 101 & 695 & 346 & 26 & 188 & 225 & 19 & 166 & 302 & 72 & 489 & 271 \\
\hline GSM - R=0\% & 117 & 719 & 220 & 24 & 106 & 42 & 13 & 115 & 168 & 83 & 482 & 146 \\
\hline GSM - R=25\% & 62 & 460 & 87 & 19 & 119 & 53 & 7 & 64 & 80 & 36 & 289 & 45 \\
\hline GSM - R=50\% & 21 & 325 & 65 & 37 & 236 & 63 & 13 & 47 & 66 & 14 & 142 & 27 \\
\hline GSM - R=75\% & 27 & 355 & 56 & 59 & 359 & 68 & 22 & 82 & 55 & 53 & 281 & 26 \\
\hline GSM - R=100\% & 65 & 516 & 44 & 82 & 487 & 71 & 32 & 132 & 44 & 95 & 498 & 22 \\
\hline
\end{tabular}

TABLE 8: RMSD of simulated grooming plus snowmaking (GSM) snowpack conditions with respect to in-situ observations (Site SM) for snow depth (SD), snow water equivalent (SWE) and density. The standard deviation of measurements was calculated for each day of observation and the average standard deviation over the season is contained in the line 'Std. dev. of obs.'). The efficiency ratio $\mathrm{R}$ is shown for each run, from $0 \%$ (no production) to $100 \%$ (no water loss).

Simulations. Table 7 shows the simulated production time, the average $T_{W}$ (when production occurred) using the standard configuration of the model (Section 2.4.3, Table 3 and 4) along with the observed production time and average water flow (also in Table 2). The model may have produced up to one night more than the observations.

The wet-bulb temperature (from SAFRAN) and the production history (daily amount of produced snow, in $\mathrm{cm}$, assuming $\rho_{\mathrm{MM}}=600 \mathrm{~kg} \mathrm{~m}^{-3}$ and $\mathrm{R}=100 \%$ ) using the standard configuration of the snowmaking model (Section 2.4.3, Table 3 and 4) are shown in Figure 13. The timing of production is consistent with the target (Table 2). In all resorts a large part of the production occurred for low temperatures : the average $T_{W}$ of production is below $-6^{\circ} \mathrm{C}$ in every resort (Table 7).

The snowmaking model provides a more accurate representation of ski slopes than natural simulations but also significantly improves the results from the grooming only simulation both in terms of snow depth and average density (Figure 14 and Table 8). The deviation between the seven configurations of the model (Table 3 and 4) is low which proves that the model is consistent and reliable when faced with slight changes of the values of parameters. However, regarding the uncertainty of the observations, the question of which configuration provides better results remains inconclusive. 


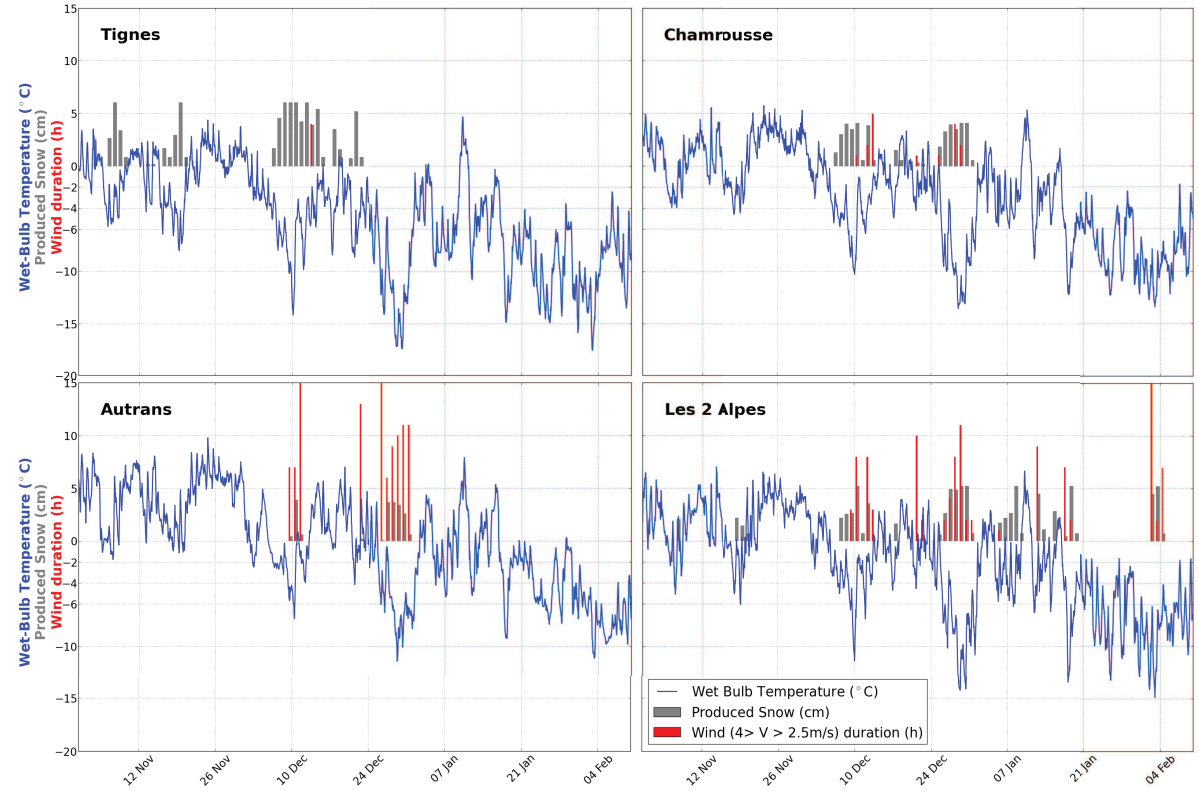

Figure 13: Wet-bulb temperature (from SAFRAN) and simulated production history (daily amount of produced snow in $\mathrm{cm}$, assuming $\rho_{\mathrm{MM}}=600 \mathrm{~kg} \mathrm{~m}^{-3}$ and no water loss i.e. $\mathrm{R}=$ $100 \%$ ) using the standard configuration of the snowmaking model (Table 3 and 4). The wind duration from SAFRAN data (wind speed $4 i \mathrm{~V}>2.5 \mathrm{~m} \mathrm{~s}^{-1}$, in hours) is shown for days when production occurred. 


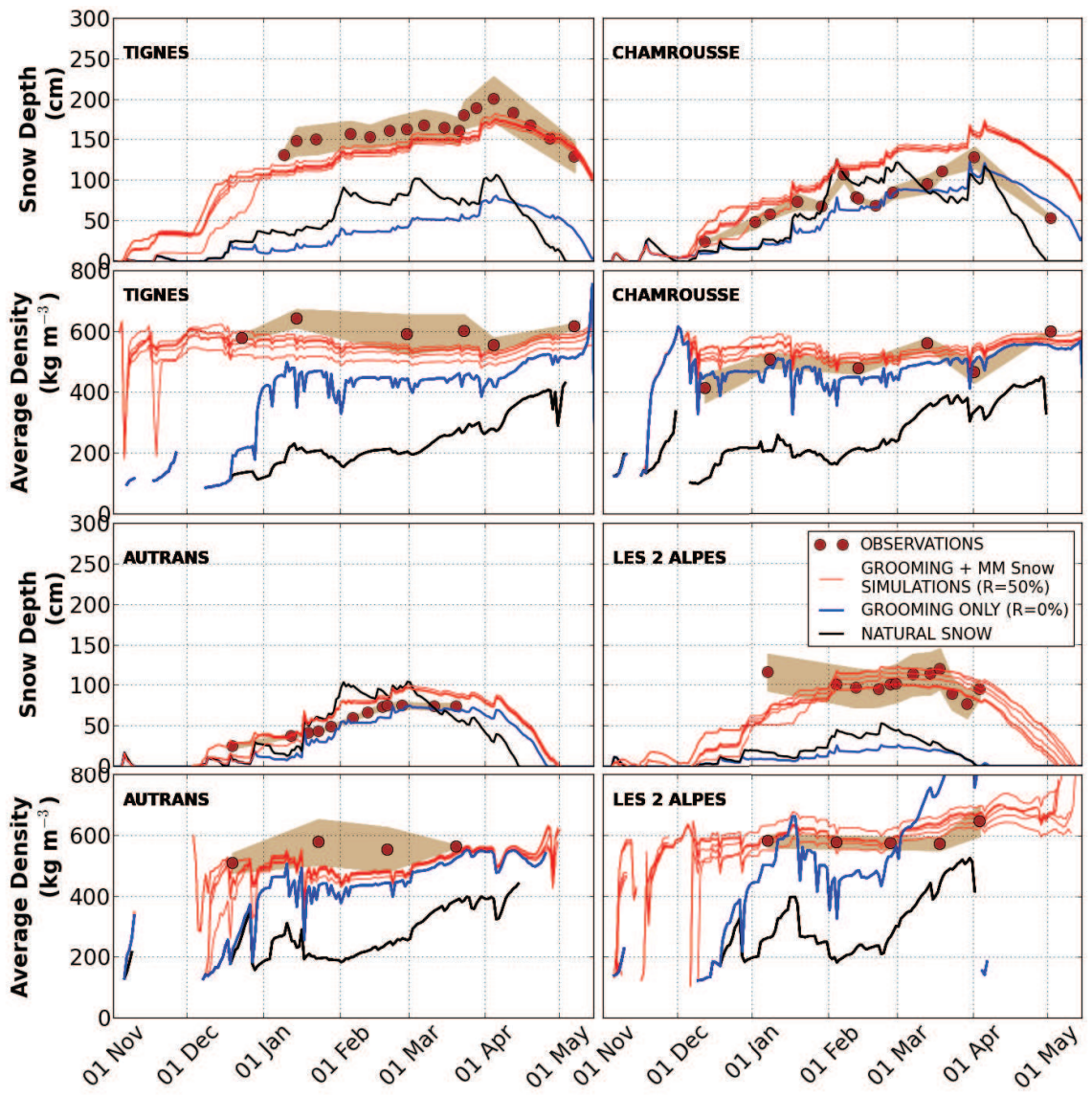

Figure 14: Grooming plus snowmaking snowpack conditions simulated by Crocus as well as in-situ observations (snow depth and average density). All seven configurations of the sensitivity test (using a ratio $\mathrm{R}=50 \%$, Table 3 and 4 ) are shown with grooming only (no production) and natural snow properties. 


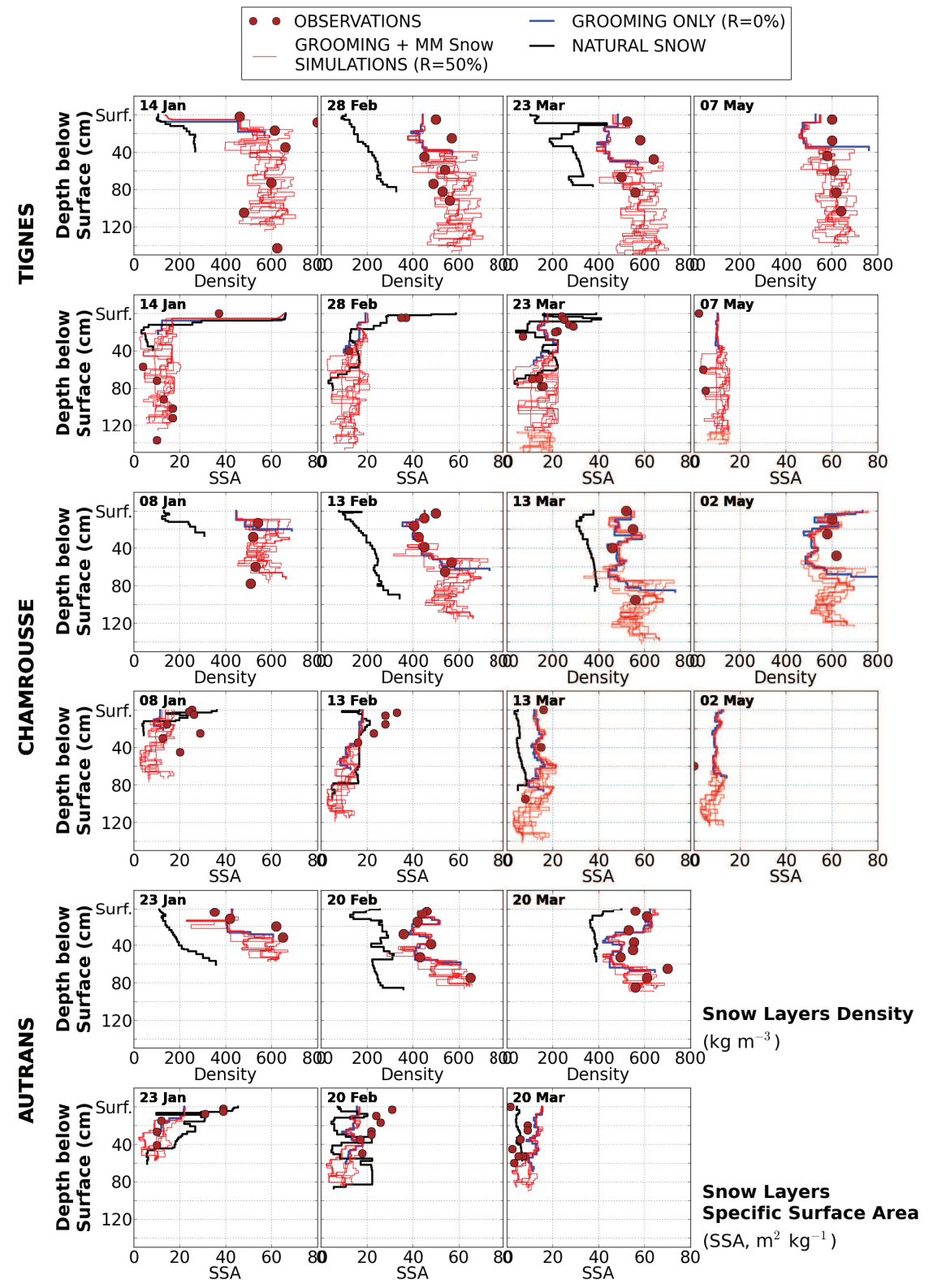

FIGURE 15: Impact of grooming plus MM snow on SSA and density profiles of the top $150 \mathrm{~cm}$ of the snowpack simulated by Crocus along with in-situ observations. All seven configurations of the sensitivity test (using a ratio $\mathrm{R}=50 \%$, Table 3 and 4 ) are shown with grooming only (no production) and natural snow profiles. 
The model clearly yields realistic snow layer properties (density and SSA, Figure 15). All SSA and density profiles from the seven configurations of the snowmaking model (Table 3 and 4) are shown with grooming only (no production) and natural snow profiles (Figure 15). There is no deviation between simulations within the top $30 \mathrm{~cm}$, as this is groomed natural snow only (section 4). Below this depth, simulation results surround the observations and provide consistent results.

Discussion. Even if neither described nor evaluated in this paper, snowmaking could be governed in the model by ongoing snowpack conditions (similarly to Hanzer et al. (2014)) and water flow derived from meteorological conditions if needed (Olefs et al., 2010). We set the values for water flow to a constant value in the model, although there is evidence that they may depend on the ongoing meteorological conditions (Olefs et al., 2010; Hanzer et al., 2014). To assess the impact of this assumption in view of the existing knowledge, the average water flow was calculated for each site using an alternative approach. This was done by using the linear equations by Olefs et al. (2010) with respect to the simulated average temperature Tw during production periods (Table 7) and with comparison to the observed constant value we used in the model (Table 2 and Equation 5). The equations by Olefs et al. (2010) provided significantly lower water flow values than the observations in Tignes, Autrans and Les 2 Alpes (air water guns, Table 7). A good agreement was found in Chamrousse (fan gun, Table 7). For example in Tignes, the simulated average temperature $T_{W}$ from SAFRAN when production occurred was $-6.5^{\circ} \mathrm{C}$, resulting in an average water flow of $8.6 \mathrm{~m}^{3} \mathrm{~h}^{-1}$ (equations by Olefs et al. (2010) for air-water guns) while the observed water flow was $12.2 \mathrm{~m}^{3} \mathrm{~h}^{-1}$ (Table 2). Hanzer et al. (2014) calibrated the coefficients of the linear relation by Olefs et al. (2010) between the water flow and the temperature in order to match the official product specifications. However this is specific to one snow gun brand and type and may not be used in other situations. Lastly, the uncertainty related to water flow is not the main issue regarding snowmaking efficiency (Table 8 , section 5.3 ). 


\subsection{Snowmaking efficiency ratio}

Observations and simulations. The best agreement (based on RMSD) between observations and simulations (section 2.4.5, Table 8) was found for an efficiency ratio $\mathrm{R}$ of $50 \%$ to $75 \%$ in Tignes, $50 \%$ to $25 \%$ in Les 2 Alpes, $25 \%$ to $50 \%$ in Chamrousse and Autrans (Figure 16 and Table 8). Even though we expected from literature (Olefs et al., 2010; Hanzer et al., 2014) that the wind and sublimation would significantly decrease the amount of water converted into MM snow on the ski slopes, the observed efficiency is lower than expected. Olefs et al. (2010) mentioned a water loss ranging between 15 and $40 \%$ for air water guns while Eisel et al. (1988)'s assessment ranged from 2 to $13 \%$ not accounting for wind effects.

Discussion. Our results point out that the most uncertain parameter for correctly simulating snow properties on ski slopes is the snowmaking efficiency ratio. In comparison with it, all other processes and parameters have a limited impact on the model's ability to simulate realistic conditions on ski slopes. Accurate estimations of water loss during snowmaking can not be provided due to the uncertainty of our observations (also dependent on the meteorological conditions of the 2014-2015 winter season). However, there is a clear distinction between the situations experienced by all four resorts during the winter of 2014-2015 (Figure 13) in which the wind may have an important role to play by significantly affecting the amount of snow reaching the ground (Pomeroy et al., 1993), particularly if slopes are surrounded by forests (Pomeroy et al., 1998). The best efficiency ratio is in Tignes where no windy conditions occurred during snow production (Figure 13, there is no vegetation either). On the contrary the worst ratio is in Autrans where windy conditions occurred for every production day and where all ski slopes are surrounded by forests. To the best of our knowledge, no extensive observation of the efficiency of snow guns has ever been reported and more detailed observations are strongly required to provide further analysis concerning this question. 


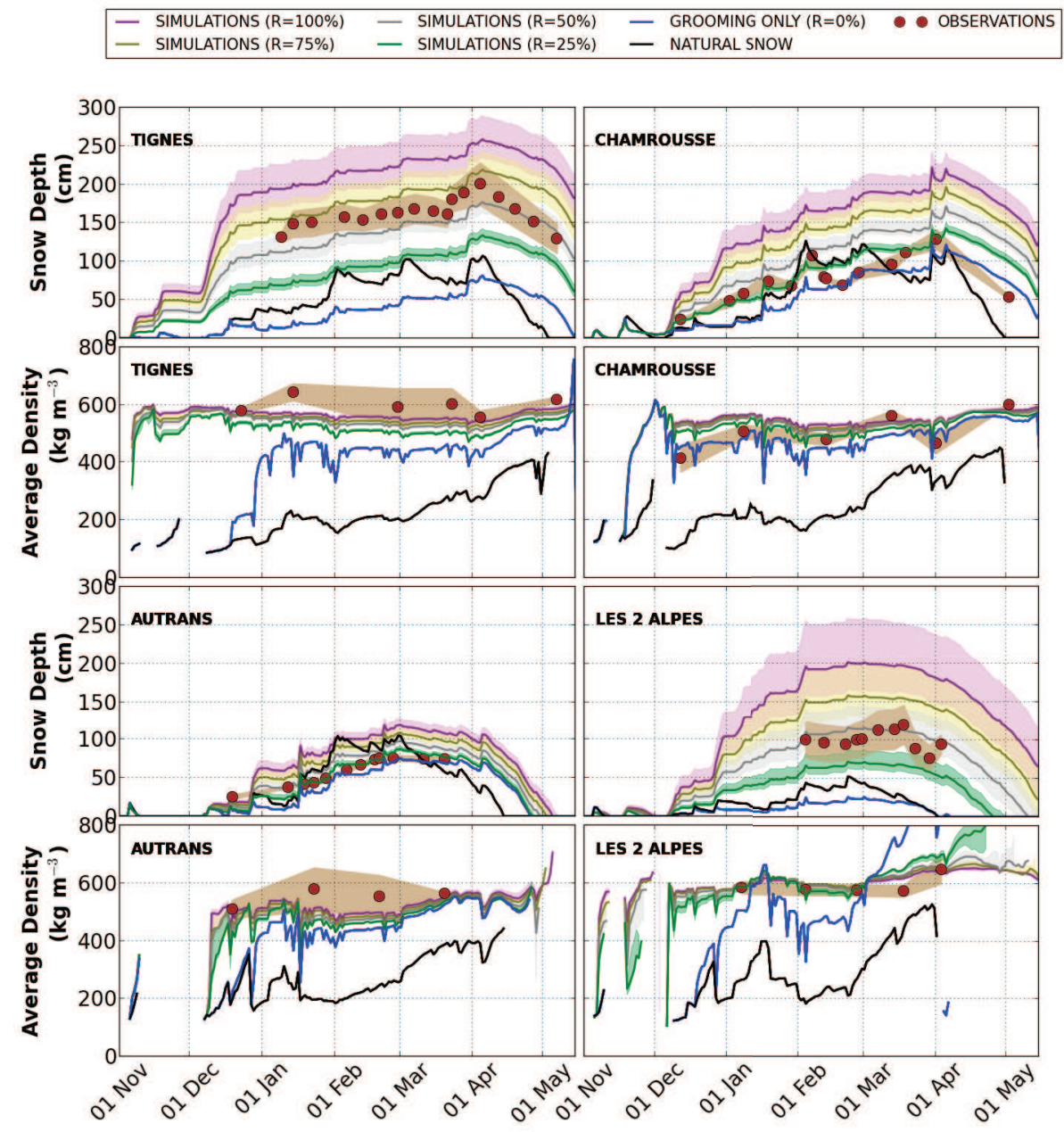

FIGURE 16: Grooming plus snowmaking snowpack conditions simulated by Crocus as well as in-situ observations (snow depth and average density). All four simulations using the standard configurations (and the most likely spreading surface $\mathrm{S}_{m i d}$ ) for the grooming and snowmaking model are shown for ratios from $\mathrm{R}=100 \%$ to $25 \%$. Envelopes correspond to the uncertainty of the spreading surface for $M M$ snow using $S_{\min }$ and $S_{\max }$ (Table 2). Grooming only (no production) and natural snow properties are also shown. 


\section{CONCLUSIONS AND OUTLOOKS}

Snow management processes (grooming and snowmaking) induce significant change to the physical state and behaviour of the snowpack. Here we described the integration of snow management processes (grooming, snowmaking) into the snowpack model Crocus. Comprehensive grooming and snowmaking approaches have been implemented in Crocus, based on the literature (Guily, 1991; Fauve et al., 2002; Olefs et al., 2010; Hanzer et al., 2014) and interviews with professionals. Each approach was evaluated with respect to in-situ measurements we carried out during the 2014-2015 winter season in four resorts in the French Alps and the sensitivity to the main parameters was tested.

The effect of the tiller is explicitly taken into account. Its effects on snow properties (density, snow microstructure) are simulated through their homogenization and modification, in addition to the compaction induced by the weight of the grooming machine. The sensitivity test showed that the model is consistent and reliable when faced to slight changes in its main parameters. The average snowpack density of groomed ski slopes ranges between 400 and $500 \mathrm{~kg} \mathrm{~m}^{-3}$ and is steadier than in natural conditions. The grooming model was proven to yield more efficiently than natural snow or even static load approach, realistic simulations of groomed ski slopes.

The specific properties of MM snow (density, specific surface area, sphericity) are taken into account in the model. The snowmaking model also provided realistic simulations of the snowpack properties with respect to observations. The sensitivity test confirmed that the model is consistent and reliable when faced to changes in parameters. The observed history of production was collected for every observation site and implemented as the production target. Even though the analysis of wetbulb temperature showed a significant deviation between $T_{W}$ measured by snow gun sensors and $T_{W}$ simulated by SAFRAN, it is shown that Crocus is able to produce snow in a realistic manner with respect to the specified rules and current meteorological conditions. The snowmaking efficiency however, i.e. the ratio between the mass of machine- made snow on slopes and the water mass used for production 
was found to be lower than expected when consulting the literature (Olefs et al., 2010) with water loss ranging from $1 / 3$ to $3 / 4$ of the total water mass consumed for snowmaking. The wind and the surrounding vegetation may have a significant impact on the snowmaking efficiency (Pomeroy et al., 1993, 1998).

The main uncertainty pertains to the efficiency of snowmaking processes and further observation and investigations need to be addressed. New developments and investigations may be considered such as taking the remaining liquid water in $\mathrm{MM}$ snow into account or a snowmaking efficiency ratio depending on meteorological conditions (wind, TW) and the sites' vegetation. Nevertheless, the model now referred to as "Crocus - Resort" has been proven to provide realistic simulations of snow conditions on ski slopes and may be used for further investigations. We expect to run simulations on a large scale : concerning the whole of the French Alps by coupling Crocus - Resort with a spatialized database gathering information on all ski resorts in these mountains (François et al., 2014). We also expect to provide relevant information concerning the ability of the snow industry to face meteorological variability in the present and, in the future, climate change challenges.

\section{ACKNOWLEDGEMENTS}

The authors wish to thank the LGGE (Laboratoire de Glaciologie et Géophysique de I'Environnement, Grenoble, France) for provision of the PICO coring auger (D. Six). We warmly acknowledge all the people who took part in this work, with special thanks to D. Amblard, P. Browaeys, F. Voegel, B. Gaget, F. Blanc, D. Maitre and A. Trinquier (Tignes ski patrol), to T. Jeandon and A. Guerrand (Les 2 Alpes ski patrol), to P. Halot, A. Traissart, Willy and J.L. Jaouen (Chamrousse ski patrol) and to J.L. Dupuis, E. Bessaguet, S. Chuberre and T. Gamot (Autrans ski patrol). Our thanks are extended to S. Riveill (Domaines Skiables de France). We gratefully acknowledge funding from Région Rhône Alpes, Labex OSUG@2020 and Fondation Eau Neige et Glace. We also wish to thank the two anonymous reviewers for their useful suggestions. 


\section{References}

Agrawala, S., et al., 2007. Climate change in the European Alps : adapting winter tourism and natural hazards management. Organisation for Economic Cooperation and Development (OECD). doi :10.1787/9789264031692-en.

Armstrong, R., Brun, E., 2008. Snow and climate : physical processes, surface energy exchange and modeling. Cambridge Univ. Pr. doi :10.1111/j.1751-8369. 2010.00181.x.

Brun, E., David, P., Sudul, M., Brunot, G., 1992. A numerical model to simulate snow-cover stratigraphy for operational avalanche forecasting. J. Glaciol. 38, $13-$ 22. URL : http://refhub.elsevier.com/S0165-232X (14) 00138-4/rf0155.

Carmagnola, C.M., Morin, S., Lafaysse, M., Domine, F., Lesaffre, B., Lejeune, Y., Picard, G., Arnaud, L., 2014. Implementation and evaluation of prognostic representations of the optical diameter of snow in the surfex/isba-crocus detailed snowpack model. The Cryosphere 8, 417-437. doi :10.5194/tc-8-417-2014.

Crowe, R., McKay, G., Baker, W., 1973. The tourist and outdoor recreation climate of ontario-volume 1 : Objectives and definitions of seasons. Atmospheric Environment Service, Environment Canada, Toronto, Canada .

Damm, A., Koeberl, J., Prettenthaler, F., 2014. Does artificial snow production pay under future climate conditions? - a case study for a vulnerable ski area in austria. Tourism Management 43, 8-21. doi :10.1016/j.tourman.2014.01.009.

Domine, F., Taillandier, A.S., Simpson, W.R., 2007. A parameterization of the specific surface area of seasonal snow for field use and for models of snowpack evolution. J. Geophys. Res. 112, F02031. doi :10.1029/2006 JF000512.

DSF, 2014. Indicateurs et analyses. URL : http://www.domaines-skiables.fr/ downloads/DSF-Indicateurs-et-Analyses2014-A4-BD . pdf.

Durand, Y., Brun, E., Mérindol, L., Guyomarc'h, G., Lesaffre, B., Martin, E., 1993. A meteorological estimation of relevant parameters for snow models. Ann. Glaciol. 
18, 65-71. URL : http://www.igsoc.org/annals/18/igs_annals_vol18_ year1993_pg65-71.html.

Durand, Y., Giraud, G., Laternser, M., Etchevers, P., Mérindol, L., Lesaffre, B., 2009. Reanalysis of 47 years of climate in the french alps (1958-2005) : Climatology and trends for snow cover. J. Appl. Meteor. Climat. 48, 2487-2512. doi :10.1175/2009JAMC1810.1.

Eisel, L.M., Mills, K.D., Leaf, C.F., 1988. Estimated consumptive loss from man made snow. JAWRA Journal of the American Water Resources Association 24, 815-820. doi :10.1111/j.1752-1688.1988.tb00932.x.

Essery, R., Morin, S., Lejeune, Y., Bauduin-Ménard, C., 2013. A comparison of 1701 snow models using observations from an alpine site. Adv. Water Res. 55, 131-148. doi :10.1016/j .advwatres.2012.07.013.

Fahey, B.D., Wardle, K., Weir, P., et al., 1999. Environmental effects associated with snow grooming and skiing at treble cone ski field. Department od Conservation 120B, 49 - 62. URL : doc.govt.nz/documents/science-and-technical/ sfc120a.pdf.

Fauve, M., Rhyner, H., Schneebeli, M., Schneebeli, M., Schneebeli, M., 2002. Preparation and maintenance of pistes : handbook for practitioners. Swiss Federal Institute for Snow and Avalanche Research SLF. URL : http://www.wsl.ch/ eshop/product_info.php?cPath=39_41\&products_id=152.

Fierz, C., Armstrong, R.L., Durand, Y., Etchevers, P., Greene, E., McClung, D.M., Nishimura, K., Satyawali, P.K., Sokratov, S.A., 2009. The international classification for seasonal snow on the ground. IHP-VII Technical Documents in Hydrology n 83, IACS Contribution n 1. URL: http://unesdoc.unesco.org/images/ 0018/001864/186462e.pdf.

François, H., Morin, S., Lafaysse, M., George-Marcelpoil, E., 2014. Crossing numerical simulations of snow conditions with a spatially-resolved socio-economic da- 
tabase of ski resorts : A proof of concept in the french alps. Cold Regions Science and Technology 108, 98-112. doi :10.1016/j.coldregions.2014.08.005.

Gallet, J.C., Domine, F., Zender, C.S., Picard, G., 2009. Measurement of the specific surface area of snow using infrared reflectance in an integrating sphere at 1310 and $1550 \mathrm{~nm}$. The Cryosphere 3, 167 - 182. doi :10.5194/tc-3-167-2009.

Guily, L., 1991. L'exploitation technique des pistes de ski alpin dans le domaine skiable français. Ph.D. thesis. Grenoble 1. URL : http://www.sudoc.fr/ 041451392.

Hanzer, F., Marke, T., Strasser, U., 2014. Distributed, explicit modeling of technical snow production for a ski area in the Schladming region (Austrian Alps). Cold Regions Science and Technology 108, 113-124. doi :10.1016/j.coldregions. 2014.08 .003$.

Howard, R., Stull, R., 2014. Piste : A snow-physics model incorporating human factors for groomed ski slopes. J. Hydrometeorol. 15, 2429-2445. doi :10.1175/ JHM-D-14-0013.1.

Huwald, H., Higgins, C.W., Boldi, M.O., Bou-Zeid, E., Lehning, M., Parlange, M.B., 2009. Albedo effect on radiative errors in air temperature measurements. Water resources research 45. doi :10.1029/2008WR007600.

Jensen, M.E., Burman, R.D., Allen, R.G., 1990. Evapotranspiration and irrigation water requirements. American Society of Civil Engineers, National Leader, Colo. Inst. for Irrig. Mgmt., USC 4th floor CSV, Ft. Collins, CO. URL : http://cedb. asce.org/cgi/WWWdisplay.cgi?67841.

Keddy, P., Spavold, A., Keddy, C., 1979. Snowmobile impact on old field and marsh vegetation in nova scotia, canada : An experimental study. Environmental Management 3, 409-415. doi :10.1007/BF01866580.

Keller, T., Pielmeier, C., Rixen, C., Gadient, F., Gustafsson, D., Stähli, M., 2004. Impact of artificial snow and ski-slope grooming on snowpack properties and 
soil thermal regime in a sub-alpine ski area. Annals of Glaciology 38, 314-318. doi : 10.3189/172756404781815310.

Koci, B.R., Kuivinen, K.C., 1984. The PICO lightweight coring auger. Journal of Glaciology 30, 244-245. URL : http://www.igsoc.org:8080/journal/30/ 105/igs_journal_vol30_issue105_pg244-245.pdf.

Lafaysse, M., Morin, S., Coléou, C., Vernay, M., Serça, D., Besson, F., Willemet, J., Giraud, G., Durand, Y., 2013. Towards a new chain of models for avalanche hazard forecasting in french mountain ranges, including low altitude mountains, in : Proceedings of International Snow Science Workshop Grenoble-Chamonix MontBlanc, pp. 162-166. URL : http://arc.lib.montana.edu/snow-science/ objects/ISSW13_paper_01-02.pdf.

Magnier, E., 2013. Neige artificielle et ressource en eau en moyenne montagne : impacts sur l'hydrosystème. Les exemples d'Avoriaz (France) et de Champéry (Suisse). Ph.D. thesis. Université Paris-Sorbonne-Paris IV. URL : https://tel. archives-ouvertes.fr/tel-00922929/.

Marcelpoil, E., Franois, H., Fablet, G., Bray, F., Achin, C., Torre, A., Barr, J., 2012. Atlas des stations du massif des Alpes. Technical Report. URL : http: //cemadoc.irstea.fr/cemoa/PUB00036588.

Marke, T., Strasser, U., Hanzer, F., Stötter, J., Wilcke, R.A.I., Gobiet, A., 2014. Scenarios of future snow conditions in Styria (Austrian Alps). J. Hydrometeorol. 16, 261-277. doi :10.1175/JHM-D-14-0035.1.

Morin, S., Domine, F., Dufour, A., Lejeune, Y., Lesaffre, B., Willemet, J.M., Carmagnola, C.M., Jacobi, H.W., 2013. Measurements and modeling of the vertical profile of specific surface area of an alpine snowpack. Adv. Water Res. 55, 111120. doi :10.1016/j.advwatres.2012.01.010.

Morin, S., Lejeune, Y., Lesaffre, B., Panel, J.M., Poncet, D., David, P., Sudul, M., 2012. A 18-years long (1993 - 2011) snow and meteorological dataset from a mid-altitude mountain site (Col de Porte, France, $1325 \mathrm{~m}$ alt.) for driving and 
evaluating snowpack models. Earth Syst. Sci. Data 4, 13-21. doi :10.5194/ essd-4-13-2012.

Olefs, M., Fischer, A., Lang, J., 2010. Boundary conditions for artificial snow production in the Austrian Alps. J. Appl. Meteor. Climat. 49, 1096-1113. doi :10. 1175/2010JAMC2251. 1

Olefs, M., Lehning, M., 2010. Textile protection of snow and ice: Measured and simulated effects on the energy and mass balance. Cold Regions Science and Technology 62, 126-141. doi :10.1016/j.coldregions.2010.03.011.

Pomeroy, J., Gray, D., Landine, P., 1993. The prairie blowing snow model : characteristics, validation, operation. Journal of Hydrology 144, 165-192. doi :10.1016/0022-1694(93)90171-5.

Pomeroy, J., Parviainen, J., Hedstrom, N., Gray, D., 1998. Coupled modelling of forest snow interception and sublimation. Hydrological processes 12, 23172337. doi :10.1002/(SICI) 1099-1085(199812) 12:15<2317: : AID-HYP799> 3.0. $\mathrm{CO} ; 2-\mathrm{X}$.

Pytka, J., 2010. Determination of snow stresses under vehicle loads. Cold Regions Science and Technology 60, 137-145. doi :10.1016/j.coldregions. 2009.10. 002.

Rixen, C., Stoeckli, V., Huovinen, C., Huovinen, K., 2001. The phenology of four subalpine herbs in relation to snow cover characteristics. IAHS PUBLICATION 270, 359-362. URL : hydrologie.org/redbooks/a270/iahs_270_359.pdf.

Rixen, C., Teich, M., Lardelli, C., Gallati, D., Pohl, M., Pütz, M., Bebi, P., 2011. Winter tourism and climate change in the alps : an assessment of resource consumption, snow reliability, and future snowmaking potential. Mountain Research and Development 31, 229-236. doi :10.1659/ MRD-JOURNAL-D-10-00112.1. 
Scott, D., McBoyle, G., 2007. Climate change adaptation in the ski industry. Mitigation and Adaptation Strategies for Global Change 12, 1411-1431. doi :10.1007/s11027-006-9071-4.

Scott, D., McBoyle, G., Mills, B., 2003. Climate change and the skiing industry in southern ontario (canada) : exploring the importance of snowmaking as a technical adaptation. Climate research 23, 171-181. doi :10.3354/cr023171.

Spandre, P., Morin, S., George-Marcelpoil, E., Lafaysse, M., Lejeune, Y., Francois, H., 2014. Integrating snow management processes and practices into a detailed snowpack model. relevance, applications and prospects, in : Presentation at the International Snow Science Workshop Banff.

Steiger, R., 2010. The impact of climate change on ski season length and snowmaking requirements in tyrol, austria. Climate research 43, 251. doi :10.3354/ cr00941.

Thumlert, S., 2013. Measurements of localized dynamic loading in a mountain snow cover. Cold Regions Science and Technology 85, 94 - 101. doi :10.1016/ j.coldregions.2012.08.005.

Vionnet, V., Brun, E., Morin, S., Boone, A., Martin, E., Faroux, S., Moigne, P.L., Willemet, J.M., 2012. The detailed snowpack scheme Crocus and its implementation in SURFEX v7.2. Geosci. Model. Dev. 5, 773-791. doi :10.5194/ gmd-5-773-2012. 


\section{HIGHLIGHTS}

H1. We integrated grooming and snowmaking approaches into the snowpack model Crocus.

H2. The model was tested and proved to be robust to the parameterization.

H3. We realized in-situ observations in four distinct French Alps ski resorts.

H4. The model provides realistic simulations with respect to these observations.

H5. The main uncertainty pertains to the efficiency of the snowmaking process. 